\title{
Maaseutu-sanan semanttinen käänne ja merkityksen muotoutuminen
}

\author{
Antti Kanner ja Torsti Hyyryläinen
}

Olemme tutkineet sanan maaseutu merkitysten muotoutumista kielen muutoksena. Analyysin aineistona olemme käyttäneet digitalisoituja suomenkielisiä sanomalehtiä 1840-1950 väliseltä ajalta. Tuloksena esitämme, että maaseutu-sanan kehityksessä tapahtui kahdessa vaiheessa 1860-1910 -luvuilla merkittävä muutos, jonka seurauksena sen yleisimmäksi merkitykseksi vakiintui kollektiivinen ja abstrakti MAASEUTU-käsite.

Nykysuomessa maaseutu ymmärretäänkin lähinnä sanan kaupunki kollektiivisen tai geneerisen, lajiin tai entiteettityyppiin yleistävästi kohdistuvan viittauksen vastakohtana: maaseutu on jotain, jota kaupunki hyvin yleisellä tasolla ymmärrettynä ei ole. Tämä käsitteellinen jäsennys yleistyi Suomessa kuitenkin vasta 1800-luvun lopulla ja liittyi ajan yhteiskunnan jännitteiseen kehitykseen ja sitä koskeviin keskusteluihin. Uudella MAASEUTU-käsitteellä oli vuosisadan vaihteessa kysyntää ja se otettiin aktiivisesti myös poliittiseen käyttöön.

Analyysimme osoittaa, että usein pysyviksi ja staattisiksi koetut käsitteelliset rakenteet ovat eläviä ja kulttuurisesti muotoutuvia. Esimerkiksi poliittiseen kielenkäyttöömme vakiintuneet käsitteet ovat abstraktioita, jotka muotoutuvat historiallisessa kontekstissa. Käsitteiden saatua kollektiivisesti jaetun sisällön niitä voidaan käyttää politiikassa ja julkisessa debatoinnissa - maaseutu on tästä erinomainen esimerkki.

Asiasanat: maaseudun käsite, maaseudut, maaseudun ja kaupungin suhde, maaseutusanan muutos, käsitehistoria, digitaalinen sanomalehtiaineisto, suomen kieli

DOI: $10.51807 /$ maaseutututkimus. 112887 
$\mathrm{K}$ ielen merkitys ajattelun, ihmisten välisen vuorovaikutuksen, yhteiskunnallisen keskustelun tai yhteistyön välineenä sekä todellisuuden luomisen tapana on yksi ihmistieteiden suurista kysymyksistä. Kieli on ehkä keskeisin ihmisten keskinäisen viestinnän välineistä. Sen synnyttämä kollektiivisen ajattelun kantokyky on kulttuurin uudistumisen ydintä. Tarkoituksemme on seuraavassa osoittaa kielen keskeinen vaikutus myös maaseudun ja kaupungin suhteen jäsentymisessä. Kieli välittää ja ilmentää tuota suhdetta.

Tutkimuksemme lingvistinen tausta on suomen kielen tutkimuksessa. Tutkimuskohteemme on maaseutu-sanan merkityksen muutos. Analysoimme kielitieteellisin menetelmin ja käsittein, miten maaseutu-sanan käyttö muuttui 1840-1950 välisenä aikana ja miten nämä muutokset yhdistyvät kaupungin ja maaseudun välisten suhteiden käsitteelliseen uudelleenjäsentymiseen sekä laajempiin yhteiskunnallisiin muutoksiin ja jännitteisiin. ${ }^{1}$

Tutkimuskysymyksemme on: miten sanan maaseutu merkitys on suomalaisessa sanomalehtikirjoittelussa muotoutunut 1840-luvulta 1950-luvulle tultaessa?

Kielitieteessä kielellä ymmärretään olevan samanaikaisesti sekä psykologinen että sosiaalinen ulottuvuutensa. Kielelliset valinnat heijastelevat samanaikaisesti niin kielen käyttäjien taipumuksia ja tavoitteita kuin kieliyhteisön vallitsevia käsityksiä siitä, mikä on kielenmukaista ja mikä ei. Näiden käsitysten varassa kielenkäyttäjät voivat luottaa kielellisen viestinsä tulevan yleisesti ymmärretyksi.

Kieliyhteisön kunakin hetkenä jakama käsitys kielen rakenteesta on varsinkin strukturalistisessa ja myöhemmin generativistisessa perinteessä hahmotettu kielitieteen varsinaisena tutkimuskohteena (de Saussure 1912, Bloomfield 1933, Karlsson 2008). Strukturalistisen perinteen jyrkkiä kahtiajakoja on myöhemmin haastettu toisaalta kielen käyttöä korostavan funktionaalisen tai käyttöpohjaisen paradigman (Kemmer \& Barlow 2000), toisaalta kielen sosiaalista, historiallista ja alueellista vaihtelua tutkivan sosiolingvistiikan suunnasta (esim. Eckert 2016, 69-70).

Kuitenkin sekä funktionaaliset suuntaukset että sosiolingvistiikan eri alalajit jakavat strukturalismin kanssa sen yleisen lähtöoletuksen, että kukin

1 Sovellamme artikkelissa kielentutkimuksen vakiintunutta merkintätapaa, jossa kielenaines merkitään kursiivilla ja merkityksen yksiköt, esimerkiksi käsitteet, merkitään KAPITEELEILLA. 
kielimuoto tai kielen historiallinen tila on ymmärrettävä sellaiseksi, että ajallisessa, sosiaalisessa tai alueellisessa kontekstissaan se on vastannut puhujayhteisönsä kommunikatiivisia tarpeita ja käytäntöjä. Näin historiallisessa tarkastelussa kieli tai kielimuoto nähdään rakenteena, joka on kokonaisuutena jatkuvassa muutoksen tilassa. Yksittäisiä kielellisiä muutoksia ei ole mielekästä tarkastella irrallaan kielestä kokonaisuutena tai historiallisesta ja kulttuurisesta kontekstistaan. Historiallisten kieliyhteisöjen kielenkäyttöön ei käytännössä ole muuta pääsyä kuin historialliset tekstiaineistot. Niiden kautta voidaan päästä kielen muutosten paikantamiseen ja kuvaamiseen.

Lähdemme siitä, että sanomalehtien kirjoitettu kieli vastaa riittävän tarkasti kirjoittajiensa käsitystä yleisesti ymmärrettävästä viestinnästä, jossa luotetaan kielen jaettuun merkityssisältöön. Julkaistut sanomalehdet ovat siten riittävän luotettava otos sisältämästään kielimuodosta kunakin ajanhetkenä. Miten jaettua kieliyhteisön sisällä vaikkapa 1860-luvun sanomalehtien kieli tosiasiassa oli, ottaen huomioon vaikkapa sosiaalisen vaihtelun lukutaidossa ja kielen alueellisen vaihtelun, on sinällään tämän kannalta epärelevanttia. Tarkastelun keskiössä eivät ole yksittäisten kirjoittajien intentiot kielellisten valintojen taustalla, vaan yleinen käsitys kielen ajallisen kehityksen hetkellisestä tilasta sosiaalisesti jaettuna järjestelmänä, joka tekee nuo valinnat mahdolliseksi.

Kielitieteellinen lähtökohtamme perustuu niin kutsuttuun käyttöpohjaiseen, käytössä elävään käsitykseen kielestä. Sillä viitataan yleisesti laajaan kirjoon teoreettisia ja metodologisia suuntauksia joille on yhteistä sekä kielellisten kokemusten korostaminen kielen rakenteen muovaajana että kielenkäytön empiirisen tutkimuksen korostaminen introspektion sijaan kielentutkimuksen pääasiallisena tutkimusmuotona (Kemmer \& Barlow 2000: ix-xv). Käyttöpohjaisen näkemyksen mukaisesti kieli uudistaa itseään jatkuvasti käytössä ja kommunikaatiossa. Mikään ei estä yksittäistä kielenkäyttäjää käyttämästä kieltä miten haluaa, mutta jos hän haluaa tulla ymmärretyksi, hänen on mukauduttava niihin käsityksiin, joita hänellä on siitä, miten hänen viestinsä todennäköisesti tullaan ymmärtämään.

Kieli on toisaalta hyvin dynaaminen, toisaalta suhteellisen hidasliikkeinen järjestelmä. Kielenmuutoksen etenemistä kieliyhteisössä on kuvattu samankaltaisilla malleilla kuin vaikkapa teknologisia innovaatioita tai epidemioita. Tyypillinen kielenmuutos etenee kieliyhteisössä logistisen funktion mukaisesti, jonka kuvaaja on niin kutsuttu S-käyrä 
(Chambers \& Trudgill 1998, 164-166). Kiinnostavaa on, milloin ja miten sanojen merkitykset ovat niin vakiintuneet, että periaatteessa kuka tahansa kielenkäyttäjä voi ottaa uuden ilmauksen käyttöön olettaen, että se ymmärretään yhteisössä suurin piirtein yhdenmukaisella ja odotetulla tavalla.

Tutkimuksen alkukohta, 1840-luku, on aikaa, jolloin sanomalehdistö alkoi Suomessa laajentua ja lehdissä julkaistiin kirjoituksia enemmän myös suomen kielellä. Suomen kieltä myös tietoisesti kehitettiin osana kansallista identiteettiä. 1950-luku puolestaan asettuu tarkastelussamme takarajaksi siitä syystä, että siihen mennessä maaseudun käsite näyttää vakiintuneen käyttöön nykyisessä merkityksessään. Tähän rajaukseen vaikuttaa myös aineiston saatavuus: Kansalliskirjaston sanomalehtikorpuksen sanamäärä ja edustavuus laskee varsin jyrkästi tuon ajankohdan jälkeen.

Nykyisin MAASEUTU määrittyy sekä kaupungin vastakohtana että maaseudulle tyypillisiksi miellettyjen piirteiden kautta. Tällaisia piirteitä ovat: yhteys luontoon ja luonnonmaisemaan, maa- ja metsätalousvaltaisuus ja harva asutus sekä mielikuvat esimerkiksi tyypillisistä maaseudun asukkaista, elinkeinoista tai poliittisista merkityksistä. MAASEUTU on nykyisin maaseutujen kollektiivinen entiteetti, johon tyypillisesti liitetään ominaisuuksia, joita yksittäisillä maaseuduilla ei välttämättä erikseen ole. Esimerkiksi kaupunkien ulkopuolella olevia teollisuuspaikkakuntia tai hiihtokeskuksia ei yleisesti mielletä tyypilliseksi maaseuduksi.

Havainnollistava esimerkki MAASEUTU-käsitteen vakiintumisesta maaseutu-sanan keskeiseksi merkitykseksi on valtakunnallisen sanomalehden nimeäminen Maaseudun Tulevaisuudeksi 1916. Lehti syntyi edustamaan valtakunnallista keskustelufoorumia ajassa, jolloin käsite MAASEUTU oli jo vakiintunut laajasti ymmärretyksi kollektiiviseksi yleistykseksi. Pitkälti tähän perustuen lehti onnistui asemoimaan itsensä koko kaupunkien ulkopuolisen Suomen - maaseudun - puolestapuhujaksi. Kuten Hyvärinen ym. käsitehistoriaa koskevassa teoksessa (2003, 9) toteavat: käsitteet ovat poliittisen kielen keskeisiä solmukohtia. Suomen historian vuosituhannen vaihteen tilanteessa abstraktiksi kategoriaksi muotoutunut MAASEUTU toimi juuri näin, ajan ilmiöitä ja intressejä tehokkaasti yhteen kietovana käsitteenä.

Vaikka MAASEUTU -käsitteen vastinpariksi voidaan hahmottaa KAUPUNGIN käsite, on kuitenkin huomattava, että kaupunki-sanalla on 
muitakin viittauskohteita kuin se, johon MAASEUTU kontrastoituu. Esimerkiksi sanaa maaseutu ei käytetä sellaisen alueellisen hallinnollisen yksikön nimenä, joka voisi toimijana tehdä päätöksiä siinä mielessä kuin voidaan esimerkiksi sanoa: Mikkelissä kaupunki päätti, että telineet siivotaan kaikista julisteista (Länsi-Savo, 19.6.2000). Tärkeä syy kaupungin laajempaan merkitysvaihteluun on, että se edustaa suomen kielessä historiallisesti huomattavasti varhaisempaa sanastollista kerrostumaa kuin maaseutu. ${ }^{2}$

Maaseutu-sanan merkityksen muutoksen tarkastelu osana kielen järjestelmää ei voi onnistua ilman että kiinnitetään samalla huomiota tämän muutoksen yhteiskunnalliseen kontekstiin, eli siihen, minkälaisessa yhteiskunnallisessa jännitekentässä ja tilanteessa sanan nykyinen kollektiivinen merkitys on muotoutunut. Tätä puolestaan ei voida tehdä ennen kuin muutoksen piirteet on paikannettu kielenkäyttöä kuvaavasta aineistosta.

\section{Aiheen merkittävyys ja rajaukset}

Maaseudun ja kaupungin suhteiden jäsentyminen on monitahoisten historiallisten, kulttuuristen, taloudellisten ja poliittisten muutosten yhteisvaikutusta. Tässä tutkimuksessa tarkastelemme tuon suhteen jäsentymistä kielen kautta mutta fokusoidusti: rajaamme analyysimme yhden sanan tarkasteluun ja jäljitämme suomenkielistä tekstiaineistoa käyttäen maaseutu-sanan muotoutumista nykyisiin merkitystehtäviinsä. Maaseutu-sanan osalta tiedossamme ei ole yhtään tällaista tutkimusta.

Olemme rajanneet toiset kotimaiset kielet eli ruotsin ja saamen tarkastelumme ulkopuolelle, ja analyysimme on kohdistunut suomenkielisiin sanomalehtiin. Rajaus on tehty tietoisena siitä, että Suomi oli osa Ruotsin valtakuntaa useiden vuosisatojen ajan, aina vuoteen 1809 asti. Ruotsin kieli vaikutti vahvasti suomalaisen yhteiskunnan kollektiiviseen ajatteluun, ihmisiin ja sukuihin sekä esimerkiksi hallintoon, lainsäädäntöön ja paikannimiin. Tutkimusotteemme ei myöskään ole vertaileva: emme tarkastele maaseutuun viittaavien sanojen muotoutumista muissa kielessä, kuten esimerkiksi englannissa.

2 Nykysuomen etymologisen sanakirjan mukaan sana kaupunki on todennäköisesti lainaa jostakin muinaisruotsin murteesta. Alkuaan kauppapaikkaa tarkoittavalla sanalla on suomen kirjakielessä historiaa Mikael Agricolasta, eli 1500-luvulta alkaen (Häkkinen 2013, 383). 
Teemme tutkimuksen alussa kuitenkin joitain huomioita suhteessa ruotsin maaseutu-vastineisiin landsortiin ja landsbygdïn, sillä niillä on ollut merkittävä vaikutus maaseudun merkitysten jäsentymisessä, mutta kovin pitkälle meneviä analyysejä emme niiden osalta tässä yhteydessä tee. Perusteellinen vertaileva tutkimus ruotsin landsortiin ja landsbygdiin olisi kuitenkin mahdollista. Sen voisi tehdä esittämiemme havaintojen pohjalta myöhemmin.

Kielitieteellisen analyysimme rinnalla olemme hyödyntäneet yhteiskuntatieteellisessä tutkimuksessa käytyä keskustelua maaseudun määrittelystä ja konstruoitumisesta yhteiskunnallisena entiteettinä. Maaseutu ja kaupunki ovat useiden tieteiden, erityisesti alueperustaisten tutkimusalojen peruskäsitteitä (key concepts), joita käytetään ja joista keskustellaan jatkuvasti. Maaseutu on kaupungin lailla tilaan kiinnittyvä ilmiö.

Molempien entiteettien käsitteellistämistä on pohdittu erityisesti niin sanotuissa alueperustaisissa tieteissä, joissa eri mittakaavaisia maantieteellisiä alueita ja paikkoja otetaan käsitteellisesti haltuun. Näin on tehty erityisesti yhteiskuntamaatieteessä (human geography) ja muissa aluetieteissä (regional studies) sekä kaupunkitutkimuksessa (urban studies). Maaseutua on käsitteenä pohdittu erityisen paljon luonnollisesti maaseutumaantieteessä (rural geography) ja maaseutusosiologiassa (rural sociology). Maaseutututkimuksessa (rural studies) maaseudun käsitettä on pohdittu ja määritelty sen muotoutumisen alkuajoista, 1950-luvulta lähtien näihin päiviin (Pratt 1996; Woods 2011; Shucksmith \& Brown 2016a).

Maaseutu- ja aluetutkijat ovat osallistuneet aktiivisesti maaseutu-sanan merkitysten määrittelyyn ja vaikuttaneet näin osaltaan MAASEUTUkäsitteen sisältöön. Tutkijat ovat tuottaneet aineksia kollektiivisiin representaatioihin maaseudusta sekä jakaneet näitä käsityksiä eteenpäin. Erityistä kysyntää on ollut maaseudun määrittelylle fyysisenä entiteettinä. Tilastoinnin lisäksi hallinto on eri maissa ottanut laajasti käyttöön tutkijoiden tekemiä luokituksia, joissa alueita tyypitellään maaseutu-ulottuvuuden mukaan. Tällaisia luokituksia tarvitaan muun muassa erilaisten politiikkojen alueelliseen kohdentamiseen. Tyypillisenä esimerkkinä voi mainita maaseudun kehittämiseen suunnattujen rahoitusten tai tukien maantieteellisten kohdealueiden määrittelyn. Myös kansainväliset järjestöt, kuten EU, OECD tai YK käyttävät tilastoinnissa tutkijoiden kehittämiä maaseutuluokitteluja. Maaseutua siis määritellään ja käsitteellistetään monien yhteiskunnallisten tahojen ja intressiryhmien käyttöön. 
Maaseutututkimuksessa kysymys kielen merkityksestä on viime vuosina noussut vahvemmin esiin. ${ }^{3}$ Kielen merkitystä on jouduttu pohtimaan, kun alan teoksia (kuten Woods 2005) ja niiden keskeisiä englanninkielisiä termejä rural ja countryside on käännetty eri kielille. ${ }^{4}$ Esimerkiksi kreikan kielessä ei ole löydetty toimivaa vastinetta, jonka merkityssisältö vastaisi termin rural sisältöä. Menelaos Gkartzion mukaan kreikan kielessä on periaatteessa kaksi sanaa, agroticos ja georgikos, jotka ovat lähimpänä englannin kielen sanaa rural. Molemmat viittaavat kuitenkin vahvasti maatalouteen. Maaseutua koskevassa kreikankielisessä kirjallisuudessa käytetään myös termiä yperthos, joka kreikan yleiskielessä viittaa kuitenkin enemmän fyysiseen luonnonympäristöön. (Gkartzio 2018, 7-11.)

Yhteiskuntatieteellisessä maaseutututkimuksessa kieleen kytkeytyvien analyysien päälinja liittyy niin sanottuun konstruktivistiseen lähestymistapaan: miten maaseutu rakentuu muuna kuin fyysisenä tilana, eli sosiaalisena, ihmisten välisen kulttuurin ja kanssakäymisen ilmiönä (Pratt 1996). Maaseutua on tästä näkökulmasta lähestytty narratiivien, diskurssien ja representaatioiden tutkimisen menetelmin. Diskurssien tutkimusta voidaan nykyisin pitää jopa yleisenä lähestymistapana maaseutututkimuksessa. Suomessa tähän liittyviä esimerkkejä maaseudun käsiteteoreettisesta tutkimuksesta ovat maantieteilijä Olli Rosenqvistin tutkimukset. Niissä keskeinen ajatus on tulkita maaseudun jäsentymistä kielen välittäminä puhuntoina, keskusteluina ja diskursiivisina kamppailuina (Rosenqvist 2004).

Kielen järjestelmän muutosten tasolla ja laajoilla tekstiaineistoilla sanan maaseutu muotoutumista ei kuitenkaan ole tutkittu. Syynä tähän voinee pitää tieteidenvälisiä, tässä tapauksessa kielitieteiden ja muiden yhteiskuntatieteiden välisiä rajoja. Näkemyksemme mukaan tieteidenvälinen lähestymistapa olisi tarpeen: kielellä on keskeinen merkitys maaseuduiksi ja kaupungeiksi jäsentyvien entiteettien rakentumisessa yhteiskunnallisiksi suhteiksi, joissa kommunikoiva ihminen on keskeinen toimija.

Rajautumista suomenkieliseen aineistoon perustelemme lisäksi sillä, että tutkijoina meillä on parempi kulttuurinen ymmärrys suomalaisesta

3 Tämä liittyy yleisemmin keskusteluun englannin kielen hegemonisesta asemasta globaalina tieteen kielenä (Phillipson 1992).

4 Englannin kielen sanan rural alkuperä on latinan sanassa rūrālis, mutta englannin kielessä sekä rural että countryside -sanojen juuret ovat 1400-luvulla (OED Online). 
maaseudusta, eli yhteiskunnallisesta ja historiallisesta käyttökontekstista, johon tutkimamme ilmaisut aineistossa kuuluvat. Jokaisessa kielessä voi nimittäin olla yllättäviä käsitteellisiä suhteita, joiden havainnointi edellyttää hyvää kielen ymmärrystä siitä, miten keskeiset käsitteet "kielentyvät", mitä merkityksiä niihin liittyy, miten käsitteet ja merkitykset liittyvät toisiinsa sekä miten sana ja sen käyttökonteksti mahdollisesti liittyvät toisiinsa.

Aiemman kielitieteellisen suomen kielen tutkimuksen suhteen tämä tutkimus asemoituu lähinnä tutkimuksiin, joissa suomen kielen 180o-luvulle sijoittuvan kehitysvaiheen (nk. varhaisnykysuomen) puitteissa kielellisten ja yhteiskunnallisten muutosten vuorovaikutusta on tutkittu yksittäisten tekstien tai tekstiaineistotyyppien näkökulmasta (esim. Laitinen 2008, Laitinen \& Nordlund 2013, Lauerma 2013). Huomio on tutkimuksissa usein kohdistunut erityisesti suomen kielen kehittämistä ohjanneisiin kieli-ideologioihin ja näiden ideologioiden yhteyksiin nationalistiseen valtioprojektiin. Esimerkiksi Nordlund \& Pallaskallio (2017) ovat tutkineet tästä näkökulmasta essiivin vartaloiden ja illatiivin päätteiden vaihtelua.

Kielikysymysten yhteiskunnalliset ja poliittiset kehykset ovat luonnollisesti kiinnostaneet myös historiantutkijoita (ks. esim. Huumo 2006, Engman 2018). Sen sijaan tutkimukset, jotka lähestyisivät muita yhteiskunnallisia muutoksia yksittäisten kielen rakenteiden näkökulmasta, ovat olleet harvinaisempia. Suomen kielen tutkimuksen ohella tutkimuksemme lähestyykin käsitehistorian intressejä (Hyvärinen 2003).

Tutkimusasetelmamme on syntynyt tieteidenvälisen pohdinnan ja yhteistyön tuloksena. Tiedossamme ei ole toista vastaavaa tutkimusta. Kyseessä onkin eräänlainen mallitutkimus siitä, miten tieteidenvälisellä otteella ja metodologisella välineistöllä saadaan mielekkäitä tuloksia. Myöhemmin tätä tutkimusotetta voidaan laajentaa kansainväliseen vertailevaan tutkimukseen.

\section{Aineistona digitoidut suomenkieliset sanomalehdet}

Tutkimus on toteutettu käyttäen Kansalliskirjaston sanomalehtikokoelman digitoituja sanomalehtiä. Kansalliskirjaston digitoitu kokoelma käsittää kaikki painetut suomenkieliset sanomalehdet 1820-luvulta 1920-luvulle, jonka jälkeen 1950-luvulle astikin aineistoa on paljon 
saatavilla. Painettujen kirjojen ja yksityiskirjeiden lisäksi sanomalehdet muodostavat keskeisen historiallisen kieliaineiston lajin. Erityisesti yhteiskunnallisen ja ajankohtaisen sisältönsä vuoksi näistä kolmesta sanomalehdet tavoittavat parhaiten sellaiset kielenkäytön rekisterit, jotka heijastavat, etenkin 1870-luvulta eteenpäin, kirjoittajiensa käsitystä vallitsevasta yleisestä kielitajusta, sillä ne suunnattiin laajalle yleisölle. Tuohon aikaan julkista yhteiskunnallista keskustelua käytiin erityisesti sanomalehtien sivuilla.

180o-luvulla tapahtunut suomenkielisen sanomalehdistön kehitys näkyy selvästi kaikissa aineiston jakaumissa. Kehitys voidaan jakaa kolmeen vaiheeseen: 1820-luvulla käynnistynyt julkaisutoiminta laajeni nopeasti, vaikka yksittäisiä julkaisuja leimasi epäsäännöllisyys ja lyhyt ikä. 1850-luvulla voimaan tullut tiukka sensuurilainsäädäntö, joka salli vain uskonnolliset ja taloudenpitoa koskevat suomenkieliset julkaisut, hillitsi julkaisutoimintaa. Sen aiheuttama stagnaatio jatkui pitkälle 1860-luvulle asti, vaikka sensuuri asteittain purettiin jo aiemmin. 1870-luvulta eteenpäin suomenkielinen sanomalehtien ja aikakauslehtien julkaiseminen kiihtyi ja laajeni: julkaisuja tuli lisää, niiden julkaiseminen tiheni ja säännöllistyi (Marjanen ym. 2019). Samalla toimitukset ammatillistuivat, ja lehtien alueellinen pohja laajeni. 1800-luvun lopussa suomenkielisen sanomalehdistön voi sanoa muotoutuneen. Yksittäiset sanomalehdet edustivat kirjavaa joukkoa poliittisia ja alueellisia intressejä, jotka heijastuivat lehtien toimituksellisessa linjassa.

Suomen kielen 180o-luvun kattavaa kehitysvaihetta kutsutaan yleisesti varhaisnykysuomeksi, joka käsittää erittäin dynaamisen siirtymävaiheen vanhan kirjasuomen ja nykysuomen välillä. Varhaisnykysuomen aikana yleiskielen murrepohja laajeni erityisesti itämurteiden suuntaan, kun monet kielen kehittäjät kokivat vanhan kirjasuomen edustaneen ahtaasti lounaismurteita ja olevan näin heikosti ymmärrettävissä muualla Suomen suuriruhtinaskunnan alueella. Sanastotyötä tehtiin runsaasti erityisesti sanakirjojen muodossa, ja yleiskieleen pyrittiin vakiinnuttamaan suomenkielisiä vastineita suomentamisen tarpeisiin.

Suomentamisella oli keskeinen osa kaikessa suomenkielisessä julkaisutoiminnassa, sillä huomattava osa tuona aikana julkaistusta kirjallisuudesta, samoin kuin esimerkiksi monet sanomalehtiartikkelit, olivat käännöksiä. Sanaston ja muiden yleiskielen rakenteiden vakiintuminen oli kuitenkin verrattain hidasta ja vaihtelevaa, joten varhaisnykysuomea leimaa huomattava ajallinen ja alueellinen vaihtelu. 
Analyysin kohteena ovat siis suomenkieliset sanomalehdet, jotka alkoivat ilmestyä 1820-luvulla. Aineisto kattaa kaikkiaan 412548 yksittäistä lehden numeroa sisältäen noin 5 miljardia yksittäistä sanaa. Tarkastelu kohdistuu erityisesti maaseutu-sanaan, joka esiintyy eri muodoissaan tässä aineistossa kaikkiaan 602070 kertaa. Kuten Häkkinen (2013) on todennut, maaseudun ensiesiintymä sanakirjoista löytyy Daniel Europaeuksen ruotsalais-suomalaisesta sanakirjasta ruotsin landsortin käännösvastineena. Elias Lönnrot oli kuitenkin käyttänyt sanaa maaseutu jo Mehiläisessä (1/1840), tosin alueen tai seudun merkityksessä.

Aineistoa on käsitelty pääosin käyttämällä Kielipankin tarjoamaa KORPkäyttöliittymää, jonka avulla Kansalliskirjaston sanomalehtikokoelmaan voi kohdistaa tarkennettuja hakuja ${ }^{5}$. Maaseutu-sanan esiintymät on koottu kohdistamalla haku sanatietueiden lemma-kenttään, joka pitää sisällään automaattisesti tunnistetun sanan perusmuodon. Lemmakenttä on monissa tapauksissa tunnistanut maaseudun lisäksi genetiivimääriteosallisia maanseutuja, mutta ne muodostavat hyvin pienen osan esiintymistä. Tarkempia määrällisiä analyysejä on tehty kohdistamalla hakuja myös viereisiin sanoihin tai maaseutu-esiintymien morfologisen analyysin sisältävään msd-kenttään. Analyysissämme hyödyntämät pronominitarkenteet on haettu sellaisista tapauksista, joissa maaseutua edeltää sija- ja lukutaivutukseltaan sen kanssa kongruoiva pronomini. Näistä esiintymistä kiinnostuksen kohteenamme olevien pronominien esiintymät on seulottu konkordanssilistasta käsin.

\section{Kielellinen analyysi}

Analyysimme lähtökohtana oli suppeammilla aineistoilla aiemmin tehty havainto maaseutu-sanan monikkomuodon vaihtumisesta yksikköön (Piispanen \& Hyyryläinen 2015 ja Hyyryläinen \& Vallas 2016). Lähdimme seuraamaan tätä havaintoa systemaattisemmin sekä laajemman aineiston kautta, eli seurasimme maaseutu-sanan yleisempien sanamuotoryhmien vaihtumista monikkomuotoisista yksiköllisiin. Etenemme tähän analyysiin tarkastelemalla kuitenkin ensin lyhyesti maaseutu-sanan varhaista muotoutumista sekä suhdetta ruotsin sanoihin landsbygd ja landsort.

5 Kansalliskirjasto 2011. Kansalliskirjaston sanoma- ja aikakauslehtikokoelman OCR-korpus (18751920) [tekstikorpus]. Kielipankki. http://urn.fi/urn:nbn:fi:Ib-201801192 
Varhaisin maaseudun esiintymä aineistossamme on Elias Lönnrotin toimittaman Mehiläisen viimeisessä vuosikerrassa tammikuulta 1840. Artikkeli "Sateen paljoudesta" sisältää kaksi maaseudun esiintymää (1a ja 1b). Ne ovat 1840-luvun ainoat esiintymät lukuun ottamatta saman artikkelin uudelleenjulkaisua Maamiehen ystävässä 1847.

1a IImasta alasputoawa wuotinen wedenpaljous on suurin maan keskiseuduilla ja wähenee sitä myöten, kun siitä tullaan likemmä maan pohjois- eli eteläpäätä , s. t. s. lampimämmillä maaseuduilla alasputoaa wuosittain enempi wettä, kun kylmemmilla

1b Mutta peräti wastahakaan on sade'päiwien luku sitä suurempi, mitä kylmempi maaseutu.

Esimerkeistä ei suoraan käy ilmi, mihin maaseutu niissä viittaa tai mikä on maa-määriteosan ja seutu-perusosan suhde. Virkkeiden aihe, ilmasto, antaa aiheen olettaa, että nykysuomen maaseudun kannalta keskeinen kontrasti kaupungin kanssa ei ole tässä kontekstissa relevantti, sillä ilmasto vaikuttaa yleisesti ottaen samalla tavalla kaupungeissa ja niitä ympäröivillä maaseuduilla. Onkin mahdollista, että maa-määriteosa pyrkii luomaan kontrastin ennemmin merialueisiin kuin kaupunkiin. Se olisi näin rakenneosiensa yhdistelmänä läpinäkyvä ja merkitsisi jotakuinkin samaa kuin maa-alue.

Esimerkissä 1b maaseutu on viittaukseltaan lajityyppiin kohdistuva eli generaalinen (Hakulinen \& Karlsson 1979, 132; Lyons 1977, 177-179) ja esiintyy geneerisessä lauseessa, joka ilmaisee ajattoman lainalaisuuden alueiden lämpötilojen ja sademäärien välisestä keskinäisestä riippuvuudesta. Geneerisen viittauksen tuottama implikaatio tässä tapauksessa kuitenkin on, että lajilla tai luokalla johon maaseutu esimerkissä viittaa, on myös konkreettisia instansseja, yksittäisiä ja yksilöitäviä maaseutuja.

Toisin kuin Mehiläisen kaksi esiintymää antavat olettaa, maaseutu 1850-luvulta eteenpäin vakiintuu nopeasti sanaksi, jota merkityksensä puolesta voisi pitää käännösvastineena sekä ruotsin landsbygdille että landsortille $^{6}$. Landsbygd merkitsee rakennettuun kaupunkialueeseen rajautuvaa aluetta, ja sitä käytetään myös määräisessä muodossa (landsbygden) silloin, kun viitataan maaseutumaisiin alueisiin kollektiivisena

6 Maaseutu esiintyi varsinkin 1850-luvulla nykyasunsa lisäksi muodoissa maanseutu ja maan seutu. Vaikka genetiivisijainen määriteosa on ollut tavallinen yhdyssanojen johtamiskeino muutenkin (ks. esim. Pitkänen 2008), voidaan genetiivillisissä muodoissa (maan seutu ja maanseutu) nähdä myös landsortin ja landsbygdin vaikutus. 1850-lukua lukuun ottamatta genetiivilliset maaseudut muodostavat kuitenkin vain hyvin pienen osan kaikista sen esiintymistä. 
kokonaisuutena. Määräistä landsbygdia vastaavaa kollektiivista käyttöä on maaseudunkin kohdalla esiintynyt jo 1850-luvulta lähtien ja se on yleinen nykysuomessakin:

2a Tällaiset tapaukset maaseudulla omat ihan jokapäiwäisiä ja tunnetut kaikille, jotka asuwat suomalaisissa seuduissa.

(Uusi Suometar no. 4 10.01.1879)

Landsort puolestaan viittaa provinsiaalisiin ja perifeerisiin alueisiin pääkaupungin tai muun keskuksen ulkopuolella. Nykyruotsiin on vakiintunut tästä sanasta vain määräinen muoto, ja kaikki alueet pääkaupungin ulkopuolella kuuluvat tähän kollektiiviseen alueeseen (Reuter 2005). Maaseudun käyttöä samantapaisessa merkityksessä edustaa esimerkki 2b:

$2 b$ Kun nyt olemme puhuneet pääkaupungin suomalaisista lehdistä, heittäkäämme silmäilys maaseudun lehtihin. Menkäämme ensin wanhaan Turkuun.

(Helsingin Uutiset 7.12.1863)

Esimerkkiä 2b olisi vaikea ymmärtää vain maaseudun kaupunkiin, tai tiiviisti rakennettuun kaupunkimaiseen alueeseen viittaavan merkityksen kautta. Kirjoittajan tarkoituksena ei kuitenkaan liene ollut implikoida, ettei Turku olisi kaupunki. Sen sijaan esimerkki 2b havainnollistaa maaseudun käyttöä provinssin tai periferian merkityksessä Helsinkiin nähden. Landsortin määräisen yksikön tapaan maaseutu viittaa tässä koko Helsingin ulkopuoliseen Suomeen.

Niin landsbygdin kuin landsortin piirteet - kontrasti kaupunkimaiseen ja tiheästi rakennettuun alueeseen ja pääkaupunkiin - kuuluvat maaseudun merkitysrakenteeseen 1850-luvulta lähtien. Ne ovat lähtökohtana kuvaukselle, jonka Kielitoimiston sanakirja nykyäänkin sille antaa. 180oluvun viimeisille vuosikymmenille saakka maaseutu eroaa kuitenkin sekä landsbygdista ja landsortista että nykysuomen maaseudusta siinä, että sitä käytetään pääsääntöisesti monikollisena. Kansalliskirjaston sanomalehtikorpuksen ruotsinkielisistä lehdistä tehtyjen hakujen perusteella yksikön määräiset muodot ovat sekä landsbygdin että landsortin kohdalla niin yleisiä, että ne kattavat yli 80 prosenttia kaikista esiintymistä.

Vaikka kaikki yksikön määräiset muodot ruotsissa eivät tietenkään aina välttämättä edusta sanojen kollektiivimerkityksiä, voidaan yksikön määräisten muotojen osuuksia pitää epäsuorana osoituksena näiden keskeisyydestä. Yksikön määräiset muodot ovat esimerkiksi landsortin 
perusosan ortin kohdalla huomattavasti harvinaisempia, ja niitä on vain hieman yli 20\% kaikista sen esiintymistä.

Maaseudun monikkomuotojen runsaus on kiinnostava ilmiö, koska toisaalta se viittaa siihen, että landsortin ja landsbygdenin määräisten yksikkömuotojen kaltainen yksiköllinen kollektiivimerkitys ei ole yleinen ja toisaalta siihen, että lähtökohtaisesti maaseutu on kategoria, joka koostuu useista jäsenistä. Monikkomuotojen runsaus viittaa edelleen myös siihen, että maaseutuja käsitellään ennemmin joukkoina kuin yksilöinä.

1800-luvun puolenvälin monikkovoittoisen kauden aikana yksiköllisellä maaseudulla on siis ollut mahdollisuus viitata määräisen landsortin tai landsbygdin tapaan kontekstuaalisesti rajautuneeseen, joko pääkaupunkiin (landsortin) tai kaupunkimaiseen, tiheästi rakennettuun alueeseen (landsbygd) kontrastoituvaan kollektiiviin, tai tiettyyn, yksilöitävään alueeseen, josta nämä kollektiivit muodostuvat. Jälkimmäinen ikään kuin vastaa niitä alueita, joiden joukkoon monikollinen maaseutu viittaa. Usein rajaa näiden kahden tulkinnan välille ei ole kuitenkaan helppo vetää, sillä mikään syntaktinen tai muu kieliopillinen piirre ei niitä tarkasti erottele. Tämä on semanttisestikin johdonmukaista, sillä yksiköllisen kollektiivisen maaseudun mahdollisuus viitata kontekstuaalisesti rajautuneeseen kokonaisuuteen on mahdollistanut jatkumon koko Suomen kaikista maaseuduista lähimpään paikalliseen maaseutuun.

Esimerkiksi kun Vaasan Sanomissa 1870-luvulla oli palsta "Kirjeitä maaseuduilta", joka vastasi sisällöltään Oulun Wiikko-Sanomien palstaa "Kirjeitä maaseudulta", ei ole oletettavaa, että alueet, joiden oloja palstoilla käsiteltiin, olisivat olleet määrällisesti lähtökohtaisesti erilaiset tai erilaisessa suhteessa lehtiensä toimituspaikkoihin. Edellisessä kontekstuaalisesti relevanttien maaseutualueiden kokonaisuuteen viitattiin monikolla, jälkimmäisessä kollektiivisella yksiköllä. Monikolliset ovat edelleen monitulkintaisia kollektiivisen ja distributiivisen viittauksen välillä (Hakulinen \& Karlsson 1979, 132).

Seuraavassa kuvaamme kvantitatiivisten indikaattorien avulla, miten edellä kuvattujen maaseudun eri käyttötapojen keskinäiset suhteet vaihtelivat 1840-1950 välisellä ajalla. Huomiomme kohdistuu erityisesti siihen, missä tahdissa yksilöitävä maaseutu katoaa käytöstä ja yksiköllisestä kollektiivisesta viittauksesta tulee maaseudun pääasiallinen käyttötapa. Tulkintamme mukaan juuri yksiköllisten kollektiivisten, ruotsin 
yksikön määräisiä landsbygdeniä ja landsortenia vastaavien maaseututapausten yleistyminen on välttämätön edellytys MAASEUTU-käsitteen vakiintumiselle maaseudun keskeiseksi merkitykseksi.

Kvantitatiivisten analyysien avulla kuvaamme, miten maaseudun käyttö muuttuu 1800-luvun jälkimmäisellä ja 1900-luvun ensimmäisellä puoliskolla. Muutokset kytkeytyvät prosessiin, joka näkyy parhaiten yksikkö- ja monikkomuotojen vaihtelussa. Suomessa monikollinen substantiivi voi viitata tarkoitteidensa joukkoon joko kollektiivisesti yhtenä jakamattomana entiteettinä tai distributiivisesti joukkoon toisistaan erottuvia diskreettejä entiteettejä. Samoin monikko voi olla määrällisesti määräinen viitaten aivan tiettyyn joukkoon tai epämääräinen viitaten summittaisesti joukkoon tarkoitteita.

Näiden välillä on suomessa kuitenkin selvä ero vain konteksteissa, jotka sallivat nominatiivin ja partitiivin välisen vaihtelun. Sekä kvantitatiivisesti määräinen (aivan tiettyyn, tunnettuun ja selvästi rajattavaan joukkoon viittaava) että epämääräinen (summittaiseen joukkoon viittaava) monikko kuitenkin itsessään yleensä edellyttää ajatuksen distributiivisen kategorian olemassaolosta, vaikka viittaus kontekstissa olisikin kollektiivinen. Iso suomen kielioppi (VISK: § 557) jakaa yksikölliset kollektiivisanat sanat kahteen kategoriaan sen mukaan onko niiden viittaus kontekstista riippumatta aina jakamaton kollektiivi, vai voiko distributiivinen tai jakamaton tulkinta vaihdella kontekstista riippuen. Ensimmäiseen ryhmään kuuluvat sanat kuten yhteiskunta ja köyhälistö, jälkimmäiseen henkilöstö, nuoriso ja yleisö.

Kuvaajaan 1 on koottu maaseudun monikkomuotojen osuus kaikista maaseudun esiintymistä aineistossamme. Siitä ilmenee, miten maaseutu menettää monikkomuotoiset esiintymänsä varsin nopeassa tahdissa. Käyrän yleinen muoto on tavanomainen kielenmuutoksille, jotka tyypillisesti etenevät noudattaen logistista S-käyrää (Chambers \& Trudgill 1998, 164-166). Logistista funktiota kuvaavalle käyrälle on ominaista hitaan käynnistymisen, nopean muutoksen ja hidastuvan muutoksen vaiheet. Nämä vaiheet ovat kuitenkin osin keinotekoisia, sillä logistisesta funktiosta ei matemaattisesti voida osoittaa erityistä pistettä, jolloin hidas muutos muuttuu nopeaksi. Maaseudun monikkomuotoja koskeva muutos on siis käynnistynyt jo 1860-luvulla, mutta siirtynyt nopean muutoksen vaiheeseen 1880-luvun loppupuolella. 


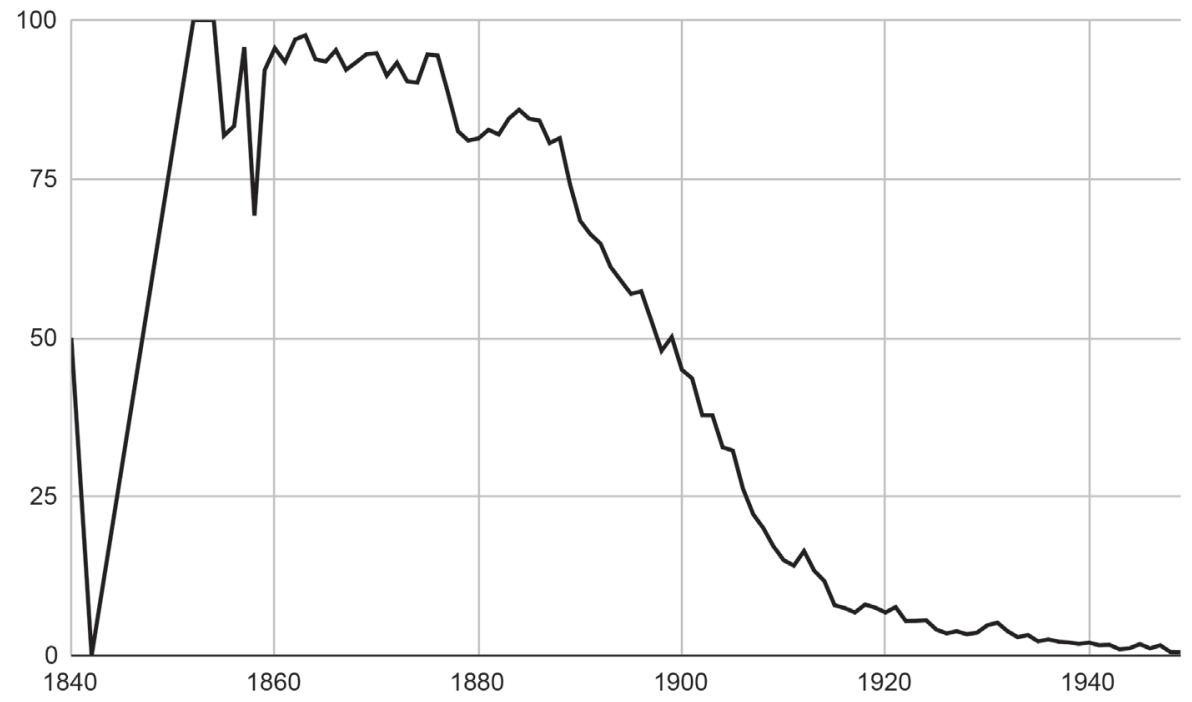

Kuvaaja 1: Maaseutu-sanan monikkomuotojen (maaseudut) \%-osuus kaikista maaseutusanoista suomenkielisessä sanomalehdissä vuosina 1840-1950 (Kansalliskirjaston sanomalehtikokoelma)

Monikkomuotojen väheneminen viittaa välillisesti kollektiivisten yksiköllisten viittausten yleistymiseen, sillä päinvastainen edellyttäisi monikkomuotojen korvautumista pääosin viittauksilla tietyn alueen yksilöiviin maaseutuihin. Näin ei kuitenkaan näytä tapahtuvan, vaan pikemminkin päinvastoin. Vaikka tietyn alueen yksilöivien maaseutujen osuutta sinällään on vaikea mitata yksinkertaisella indikaattorilla, sijaismuuttujana voidaan käyttää sellaisia maaseudun esiintymien piirteitä, jotka monikon tapaan edellyttävät, että maaseudut muodostavat yksilöitävistä alueista koostuvan joukon. Näiden piirteiden on oltava lauseyhteydessään helposti automaattisesti tunnistettavia ja laskettavia, sillä aineiston syntaktinen koodaus on epäluotettavaa ${ }^{7}$.

Näillä kriteereillä tutkittaviksi piirteiksi valikoituivat pronominitarkenteet. Ne oli suhteellisen helppo seuloa yleisimpien maaseutua välittömästi edeltävien sanojen joukosta rajaamalla KORP-haku maaseutua edeltävät pronominit luku- ja sijakongruenssin perusteella ja käymällä esiintymät käsin läpi. Maaseutua pronominitarkenteiden joukossa on

$7 \quad$ Kielipankin ylläpitämä versio Kansalliskirjaston sanomalehtikorpuksesta on esikäsitelty syntaktisella jäsentimellä, joka on tunnistanut automaattisesti jokaisen sanan syntaktiset dependenssisuhteet. Jäsennys on kuitenkin laadultaan epäluotettava. 
kaksi ryhmää, joiden voi ajatella laskennallisesti erottelevan kollektiivisesti ja yksilöivästi viittaavat yksikölliset maaseudut.

Ensimmäisen ryhmän näistä muodostavat kvanttoripronominitarkenteet (kuten moni, usea, jokainen), jotka ilmaisevat tarkkaa tai summittaista lukumäärää ja edellyttävät jaottomien entiteettien joukkoja (VISK: § 762). Ne käyttäytyvät siis samoin kuin monikkomuodot siinä suhteessa, että ne edellyttävät ajatuksen monilukuisesta kategoriasta olevan mielekäs.

3a Olen siitä wakuutettu että koko rautatien warsi Turusta Pietariin odottaa suomalaista päiwälehteä, odottaa moni maaseutu ja kaupunki, joihin warsinkin kesällä laiwaliikkeiden awulla tulee posti joka päiwä.

(Uusi Suometar 30.08.1880)

Toisen ryhmän muodostavat määräisyyden ja epämääräisyyden ilmauksina käytetyt pronominitarkenteet, sillä niiden avulla kirjoittaja tai puhuja suhteuttaa viittaamansa kohteen mahdollisten kohteiden joukkoon. Yleisimmät määräisyyttä osoittavat tarkenteet kuuluvat demonstratiivipronomineihin (tämä, tuo, se) ja epämääräisyyttä ilmaisevat indefiniittisiin kvanttoripronomineihin (joku, eräs, yksi) ja proadjektiiveihin (kuten sellainen, tuollainen, eräänlainen) (VISK: §1410-§1416). Vaikka määräisyyttä tai epämääräisyyttä ei tarvitse aina eksplisiittisesti osoittaa, näiden ilmausten läsnäolo edellyttää vaihtoehtoisten tulkintojen mahdollisuuden.

3b Jäältä nähtiin muskus-härkiä, peuroja, jääkarhuja, jäniksiä ja walkoisia kettuja, mutta eo paljon, sillä tämä maaseutu ei kaswanut heinää eikä paljon jäkälöitäkään ja sentähden löytyy siellä wähä eläimiä ja lintuja.

(Suometar 31.8.1855)

3c Näytelmäpaikka osoittaa erästä maaseutua Hämeessä

(Otawa 19.1.1861)

3d Jos sitte wielä määräpaikka ei olekaan kaupunki, waan joku maaseutu, niin uudistetaan samat maksut, niin että sen kirjeen liika-menot tulewat tyyrimmäksi itseä päämaksua, postirahaa.

(Oulun Wiikko-Sanomia 6.10.1860)

Niin sanotut luontaisesti tunnistettavien substantiivien (VISK: $§ 1409$ ), kuten kuu, aurinko tai maapallo, määräisyyttä tai epämääräisyyttä harvoin ilmaistaan, sillä niitä ajatellaan kontekstissaan olevan vai yksi kerrallaan. Koska yksiköllinen kollektiivinen maaseutu kokoaa yhtenäiseksi 
entiteetiksi kaikkien kontekstissaan relevanttien maaseutualueiden kokonaisuuden, se on yleensä samalla tavalla luontaisesti tunnistettava. Tiettyyn, yksilöitävään alueeseen viittaava maaseutu sen sijaan käyttäytyy tavanomaisen substantiivin tavoin ja on ilmaistava määräiseksi tai epämääräiseksi kontekstin niin vaatiessa.

Vaikka yksiköllisen maaseudun kollektiivisuuden aste hahmotettaisiin jatkumoluonteisena siten, että se voi enemmän tai vähemmän korostua, määräisyyden ja epämääräisyyden ilmauksia voidaan käyttää indikaattorina tämän jatkumon määrällisen jäsentymisen kuvaamiseen. Tämä perustuu siihen, että kollektiivisen yksiköllisen maaseudun kohdalla määräisyyteen ja epämääräisyyteen liittyvät ilmaukset ovat epätodennäköisempiä kuin yksilöivän maaseudun kohdalla. Tilanne ei muutu, vaikka asiaa lähestyttäisiin jatkumon näkökulmasta: mitä enemmän kollektiivisuus korostuu, sitä pienemmäksi laskee määräisyyttä tai epämääräisyyttä ilmaisevien piirteiden todennäköisyys. Taulukossa 1 on esitetty edellä mainittuihin kahteen prononimitarkenteiden ryhmään kuuluvat esiintymät maaseudun yhteydessä.

Taulukko 1: Pronominitarkenteellisten maaseutu-sanojen määrät ja osuudet suomenkielisissä sanomalehdissä 1850-1949 (Kansalliskirjaston sanomalehtikokoelma)

\begin{tabular}{|l|l|l|l|}
\hline Ilmestymisvuosi & $\begin{array}{l}\text { Pronominitarkenteel- } \\
\text { liset maaseudut }\end{array}$ & $\begin{array}{l}\text { Kaikki } \\
\text { maaseudut }\end{array}$ & $\%$ \\
\hline $1850-1859$ & 3 & 318 & 0.94 \\
\hline $1860-1869$ & 33 & 4344 & 0.76 \\
\hline $1870-1879$ & 82 & 11032 & 0.74 \\
\hline $1880-1889$ & 129 & 38056 & 0.34 \\
$1890-1899$ & 236 & 113323 & 0.21 \\
\hline $1900-1909$ & 163 & 213422 & 0.08 \\
\hline $1910-1919$ & 72 & 82456 & 0.09 \\
\hline $1920-1929$ & 49 & 40878 & 0.12 \\
\hline $1930-1939$ & 56 & 56161 & 0.10 \\
\hline $1940-1949$ & 20 & 28369 & 0.07 \\
\hline
\end{tabular}

Maaseudun yhteydessä esiintyvien pronomintarkenteiden kokonaisfrekvenssi laskee tarkastelujakson aikana suurin piirtein samassa tahdissa kuin monikkomuodot. Laskeva frekvenssi osoittaa, että kollektiivinen yksiköllinen maaseutu hyvin todennäköisesti yleistyy tarkastelujakson aikana, sillä mikäli näin ei olisi, pronominitarkenteiden frekvenssin 
pitäisi kasvaa. Taulukon kuvaama muutos osuu kuitenkin ajoitukseltaan hyvin yhteen monikkomuotojen harvinaistumisen kanssa: molemmissa nopean muutoksen vaihe ajoittuu 1800 -luvun kahdelle viimeiselle vuosikymmenelle. Voidaan siis ajatella, että monikkomuotojen ja näiden pronominitarkenteiden väistymisessä on kyse toisiinsa liittyvistä ilmiöistä. Taulukon kuvaama muutos ei liity myöskään mihinkään koko aineistoon yleisesti vaikuttavaan tekijään, sillä esimerkiksi maaseudun pääosan seudun kohdalla vastaavaa muutosta ei ole havaittavissa.

Edellä esitetyn perusteella semanttisesti maaseudun esiintymät jakaantuivat karkeasti kolmeen merkitystyyppiin: 1) varsin yleisellä tasolla alueeseen tai seutuun $(4 \mathrm{a}), 2$ ) landsortin tapaan provinsiaaliseen, pääkaupunkiin tai muuhun keskukseen kontrastoituvaan alueeseen (4b) tai 3) landsbygdin tapaan kaupunkimaisesti rakennettuun alueeseen kontrastoituvaan seutuun (4c). Lisäksi kaikki nämä sallivat sekä yksilöivän että kollektiivisen viittauksen sekä monikossa että yksikössä.

\begin{abstract}
4a Toinen merkittäwä kohta on että koko se lawea maaseutu, jonka rajana olisi etelässä keskinen emärata ja idässä tuo pohjoiseen päin kulkewa linja, ei tulisi osalliseksi uuden ajan kulkuneuwoihin.
\end{abstract}

(Uusi Suometar 16.5.1877)

4b Toimisto sulkeutuu etenkin maaseudun kuntain ja kaupunkien huomioon warmistaaksensa riitinkiä kunnallisiin rakennuksiin - -

(Hämeen Sanomat 1.10.1879)

4c Ja kuitenkin on ympäröiwä maaseutu wallan suomenkielinen, ja itse kaupungissa kuulee monin werroin enemmän suomea kuin ruotsia!

(Vaasan Sanomat 4.8.1879)

Edelleen kaikki yksikölliset ja monikolliset esiintymät ovat voineet olla viittaukseltaan sekä kollektiivisia että (yksikön tapauksessa) yksilöiviä tai (monikon tapauksessa) distributiivisia, eli viitata toisistaan erottuvista osista koostuvaan joukkoon. Edellä osoitettiin, miten näistä tyypeistä kaikki muut paitsi yksikölliset, viittaukseltaan kollektiiviset merkitykset harvinaistuivat samassa tahdissa: ensin hitaasti 1860-luvulta alkaen ja sitten nopeasti $1800-l u v u n$ kahdella viimeisellä vuosikymmenellä. Valitut esimerkit $4 \mathrm{a}-\mathrm{c}$ ovat kuitenkin epätyypillisempien esiintymien joukosta, sillä yleisin maaseudun muoto 1800-luvun puolivälin jälkeen on monikollinen ja ulkopaikallissijainen. 


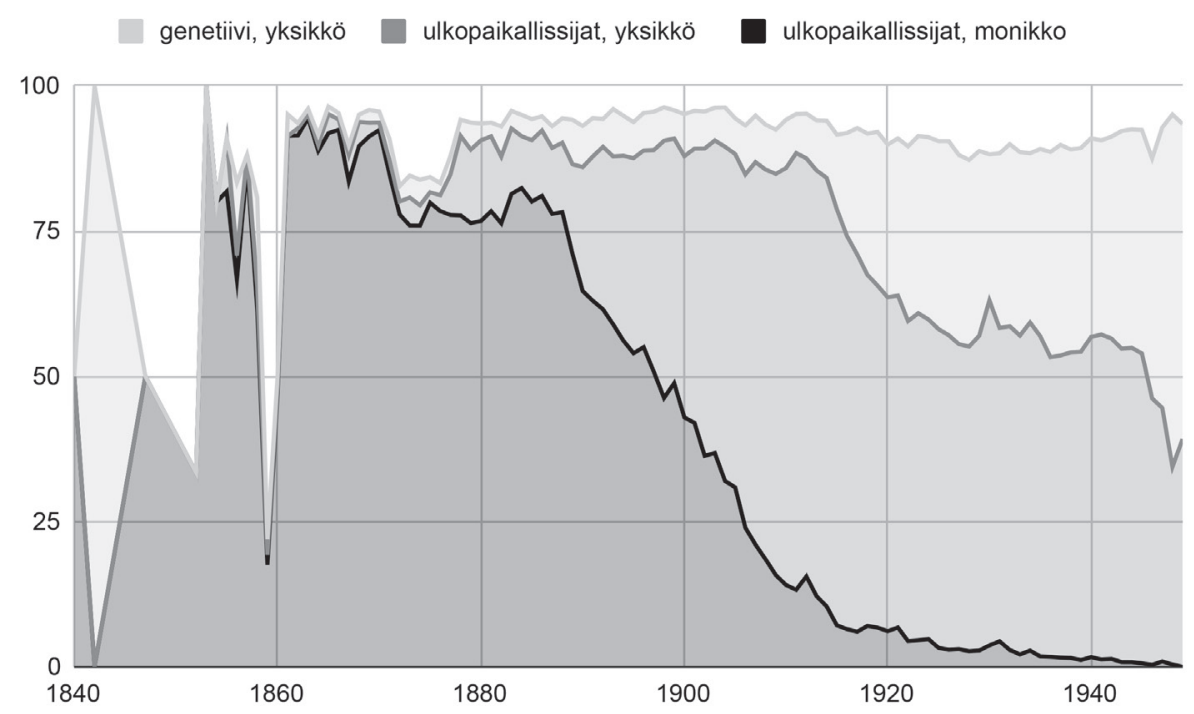

Kuvaaja 2: Yleisimpien maaseutu-sanan taivutusmuotoryhmien osuudet kaikista maaseutusanan esiintymistä suomenkielisissä sanomalehdissä vuosina 1840-1950 (Kansalliskirjaston sanomalehtikokoelma)

Maaseutu esiintyy lauseissa adverbiaaliasemassa osoittamassa lauseen kuvaaman tilan tai tapahtuman paikkaa tai sijaintia. Tämän voi osoittaa tarkastelemalla tarkemmin maaseudun sijamuotojakaumia ja niiden vaihtelua tarkastelujaksolla. Kuvaajaan 2 on koottu maaseudun kolme yleisimmän muotoryhmän (monikon ulkopaikallissijojen, yksikön ulkopaikallissijojen ja yksikön genetiivin) osuudet kaikista maaseudun esiintymistä.

Maaseudun ulkopaikallissijojen käyttö liittyy suoraan sen esiintymiin adverbiaaliasemissa. Näille adverbiaalitapauksille on huomionarvoista, että ne eivät usein tee eroa edellä kuvattujen merkitystyyppien välillä, vaan esiintymät ovat epämääräisiä (vague) tai monitulkintaisia (ambiguous) näiden välillä (ks. esim. Tuggy 1993). Erot kolmen merkitystyypin välillä ovat adverbiaali-maaseutujen kontekstissa usein epärelevantit. Tämä johtuu osaksi siitä, että näitä maaseudun merkityksiä sitovat toisiinsa vahvat implikaatiot. Yksilöity, provinsiaalinen maaseutu on toisaalta maantieteellinen alue ja kontrastoituessaan paikalliseen kaupunkiin tai muuhun asutuskeskukseen se on usein myös maaseutumainen suhteessa keskuksensa tiiviiseen kaupunkimaiseen asutukseen. Kolme merkitystä voivat siis adverbiaalitapauksissa useimmiten elää sovussa 
samassa esiintymässä ilman väärinymmärryksen vaaraa, koska eroavaisuudet niiden välillä eivät ole asiayhteydessään relevantteja.

Monikon ulkopaikallissijoille on tyypillistä, että ne eivät tee eroa kvantitatiivisen määräisyyden ja epämääräisyyden välille. Suurimmassa osassa tapauksia maaseudun esiintymät ovat olleet siis avoimia niin kvantitatiivisesti määräiselle kuin epämääräiselle ja distributiiviselle ja kollektiiviselle tulkinnalle samanaikaisesti. Adverbiaaliasemassa toimivan sanan viittauksen suhteen erot näiden välillä eivät usein olekaan merkityksellisiä.

Kuvaajasta 2 käy ilmi, miten monikon ulkopaikallissijat korvautuvat ensisijaisesti yksikön vastaavilla. Tätä voidaan pitää edelleen viitteenä nimenomaan yksikön kollektiivikäytön lisääntymisestä, sillä kollektiivinen monikko ja kollektiivinen yksikkö eivät usein kontrastoidu voimakkaasti toisiinsa. Muutoksen alkuvaiheen rajautuminen näin tarkasti ulkopaikallissijoihin ja nimenomaan siten, että muutos tapahtuu tämän muotoryhmän sisällä viittaa siihen, että merkityksen tasolla muotojen välillä on luonteva jatkumo.

Kollektiiviset viittaukset muodostavat siis eräänlaisen välittävän kontekstin, jonka sisällä muutos voi edetä ilman vaaraa ymmärrettävyyden heikkenemisestä. Maaseudun tyypillisessä syntaktisessa käytössä ei siten aluksi tapahdu suurta muutosta. Monikolliset ulkopaikallissijaiset muodot (kuvaaja 2, tummin alue) kattavat noin kolme neljäsosaa kaikista maaseudun esiintymistä pitkälle 1880-luvun loppupuolelle asti. Tästä eteenpäin monikkomuodot alkavat vähentyä hyvin nopeassa tahdissa, kun tullaan logistisen S-käyrän nopean muutoksen vaiheeseen. Yksikölliset ulkopaikallissijaiset muodot (keskimmäinen alue) ovat korvanneet ne melkein kokonaan 1910-luvulla. Maaseudun syntaktisessa käyttäytymisessä tapahtuu kuitenkin muutos 1910-luvun puolenvälin jälkeen, kun yksikön genetiivit (kuvaajan vaalein alue) nousevat yksikön ulkopaikallissijojen rinnalle vallitsevaksi muodoksi.

Genetiivillä on suomen kieliopissa paljon eri käyttöjä, mutta nämä maaseudun esiintymät ovat huomattavan suureksi osaksi genetiivimääritteitä. Elotontarkoitteisen genetiivimääritteen (kuten maaseudun) ja sen pääsanan suhde ilmaisee tavallisesti jonkinlaista yhteenkuuluvuutta (VISK: § 574), joka määrittyy näiden sanojen semanttisesta rakenteesta. 
Läpi tarkastelujakson suurimman osan esiintymistä kattaa ihmisiin ja ihmisryhmiin viittaavat sanasto, kuten ihminen, asukas, väki, yleisö sekä instituutioihin, palveluihin ja ammatteihin liittyvä sanasto, kuten postikonttori, pappila, koulu, lehti, opettaja. Toki sanasto näiden kategorioiden sisällä rikastuu periodin loppupuolella esiintymätiheyden kasvaessa. Näiden kahden ryhmän rinnalle ilmestyy kaksi uutta ryhmää, kun genetiiviattribuutit alkavat voimakkaasti yleistyä: maaseudun tunnelmaan liittyvät sanat, kuten hiljaisuus ja rauha sekä tarkoitteiltaan abstrakteihin prosesseihin tai olosuhteisiin viittaavat sanat, kuten tulevaisuus, olo, elinkeino, tarve, turva ja sähköistys.

Yksikölliseen, todennäköisesti useimmin kollektiiviseen, maaseutuun siirtymistä voidaan seurata myös lehdittäin, jolloin voidaan havainnoida sitä, miten muutos eteni eri sanomalehdissä maan eri osissa. Alla olevassa kuvaajassa 3 näkyy sanomalehdet, joissa sana maaseutu esiintyy aineistossamme useimmin. Ruutujen väri kuvaa kunkin lehden jokaisen vuoden jakaumaa monikollisten ja yksiköllisten maaseutujen kesken. Mitä vaaleampi väri, sitä enemmän yksiköitä suhteessa monikoihin Täysin valkoinen väri tarkoittaa, ettei lehteä ole tuona vuonna julkaistu tai se ei ole sisältänyt yhtään maaseudun esiintymää. Lehdet on järjestetty siten, että mitä aiemmin ensimmäinen vuosikerta, jona yksiköllisten osuus on 50 \%, sitä korkeammalle julkaisu sijoittuu.

Kuvaajasta 3 (seur. sivulla) käy ilmi, että muutos käy läpi suurimmat sanomalehdet varsin ripeässä tahdissa. Myöhäisimmätkin lehdet siirtyvät puhumaan useimmiten yksiköllisestä maaseudusta ennen vuotta 1910. Vastaavasti muutoksen etunenässä kulkevatkaan lehdet eivät taivu uudelle kannalle aiemmin kuin 1890-luvun ensimmäisinä vuosina. Toiseksi, kuvaajasta erottuu selviä rakenteita: lehdet, jotka kulkevat muutoksessa kärjessä näyttävät olevan Päivälehteä lukuun ottamatta PohjoisSuomen, Pohjanmaan ja Savo-Karjalan alueelta. Ennen kaikkea kuvaaja osoittaa sen, että muutoksessa ei ole kyse siitä, että maaseudun yksiköllinen käytöllä olisi ollut vahvat perinteet tietyissä sanomalehdissä ja muu lehdistö olisi 180o-luvun lopussa taipunut niiden kannalle, vaan muutos käy läpi koko suomenkielisen sanomalehdistön varsin ripeässä tahdissa.

Edellä esitetyn kielellisen analyysin ja tekemiemme havaintojen perusteella hahmottelemme seuraavan muutosprosessin: alkupisteessään, 180o-luvun puolessavälissä, maaseutu on voinut viitata tiettyyn yksilöitävään alueeseen, jolla on joko pelkän seudun tapaan jonkinlainen yksilöllinen identiteetti, tai pääkaupunkiin kontrastoituvaan provinsiaaliseen 


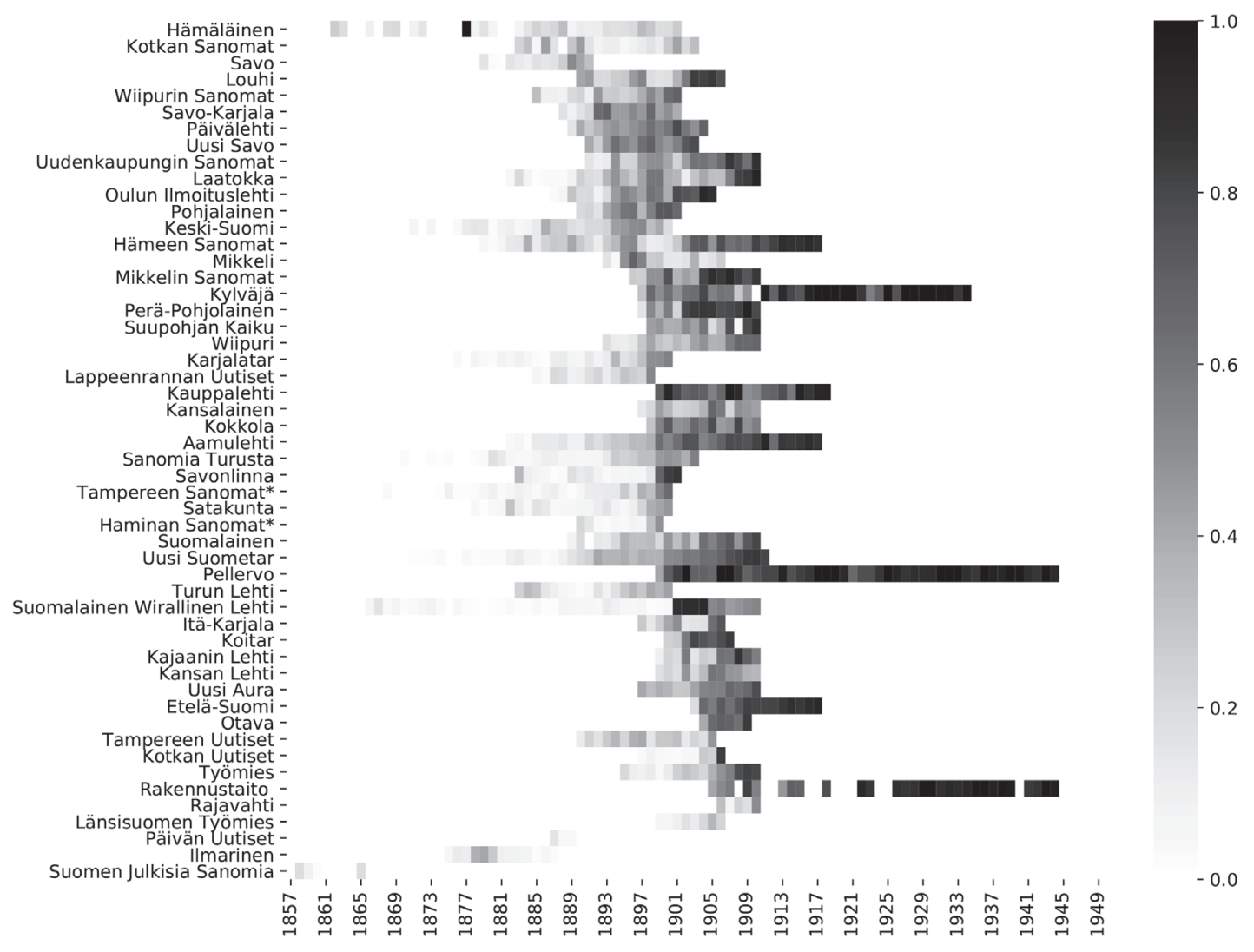

Kuvaaja 3: Monikollisten ja yksiköllisten maaseutu-sanojen ilmenemisintensiteetti eri sanomalehdissä Suomessa 1857-1949 (Kansalliskirjaston sanomalehtikokoelma)

alueeseen ruotsin landsortin tapaan tai kaupunkimaisesti rakennettuun alueeseen kontrastoituvaan alueeseen ruotsin landsbygdin tapaan.

Yleisin käyttötapa ennen 1860-luvulla käynnistynyttä asteittaista muutosta on ollut käyttää maaseutua kuitenkin monikollisena ja adverbiaaliasemissa. Erityisesti sitä on käytetty konteksteissa, jotka eivät ole tehneet eroa kolmen edellä luetellun merkityksen välillä. Koska useimmat tällaiset esiintymät eivät ole tehneet eroa toisaalta kvantitatiivisen määräisyyden ja epämääräisyyden ja toisaalta kollektiivisen ja distributiivisen tulkinnan välillä, ne on voitu korvata kollektiivisella yksiköllä, joka monilta ominaisuuksiltaan vastaa monikkoja. Sekin jättää viittauksen tarkan alan asiayhteydessään yleensä avoimeksi. 
Maaseutu alkaa siis saada itsenäistä asemaa käsitteenä, kun yksiköllisestä kollektiivisesta maaseudusta tulee sen useimmin käytetty esiintymätyyppi. Kollektiivinen MAASEUTU nousee abstraktiotasoltaan korkeammalle tasolle ja alkaa viitata yksilöitävän alueen sijaan tietyntyyppisiin alueisiin kollektiivisena kokonaisuutena. Samalla se alkaa viitata niihin käsitteellisiin piirteisiin, jotka kollektiivikategorian jäsenille yleisesti hahmotetaan. Näiden piirteiden osalta MAASEUTU alkaa kontrastoitua kaupungin käsitteeseen vastaavalla, yleisellä abstraktiotasolla.

Muutoksen myötä MAASEUDUN sisällöksi tulevat käsitteelliset piirteet, jotka ovat kaupungin geneeristen piirteiden vastakohtia. On oleellista havaita, että näin syntyvä vastakohtasuhde maaseudun ja kaupungin välillä irtoaa siitä, miten nämä piirteet jakautuvat tiettyjen kaupunkien ja niitä ympäröivien tiettyjen maaseutualuiden kesken. Tämän myötä maaseutua on myös voitu käyttää vapaammin asioiden luonnehtimiseen, kun sen käsitteelliseen keskiöön ovat tulleet piirteet, jotka kaikki maaseudut jakavat. Kollektiivisen maaseudun merkityksen vakiintuessa siihen voidaan liittää ominaisuuksia, jotka tavallisesti kuuluvat yksilöllisille entiteeteille, kuten tarpeita, tulevaisuuksia ja uhkia.

Eräänlaisena päätepisteenä muutokselle voidaan pitää Länsi-Savossa 10.12.1917 ilmestynyttä kirjoitusta "Kansallinen kokoomus ja kansanpuolue", josta on peräisin esimerkki 6a:

\begin{abstract}
6a: - - Maamme väestöstä on 85 pros. maalaisia. Ja kun varsinkin sota- ja kumousaika on näyttänyt, että maalaisväestön hyvinvoinnista ja sen harjoittaman elinkeinon menestymisestä riippuu koko kansan säilyminen ja voima, niin on mitä tärkeintä, että tämä maaseutu myös saadaan kokonaisuudessaan herätetyksi ja kohotetuksi sekä aineellisesti että henkisesti.
\end{abstract}

(Länsi-Savo 10.12.1917)

Esimerkin maaseutu onkin jo täysin nykysuomen mukainen. Erityisen huomionarvoinen on sen saama demonstratiivipronominitarkenne tämä. Esimerkissä maaseudulla tarkoitetaan abstraktiota, joka muodostuu poliittisesti aktiivisesta väestönosasta ja maaseudun elinkeinoista. Kollektiivitulkintaa tukee edelleen adverbiaali kokonaisuudessaan. Sattumaa ei liene sekään, että esimerkin 6a konteksti on eksplisiittisesti poliittinen.

Tässä vaiheessa maaseudusta on tullut lukevan yleisön helposti tunnistama keino jäsentää ja luokitella alueellista ja poliittista käsitteellistä avaruutta. Se ei tässä tarkenna tiettyä aluetta muiden alueiden joukosta 
(esimerkiksi Länsi-Savon maaseutua erotuksena Savo-Karjalan maaseudusta), niin kuin pronominitarkenteet tekivät kymmenen vuotta aiemmin. Sen sijaan se viittaa tiettyyn tapaan ajatella maaseutua kollektiivina ja abstraktiona, joka erottuu muista mahdollisista tavoista ajatella ja määritellä maaseutua käsitteenä.

\section{Käänteentekevän muutoksen 1850-1910 tulkintaa}

Olemme tutkineet laajaa sanomalehtiaineistoa käyttäen, miten sana maaseutu on muotoutunut suomalaisessa sanomalehtikirjoittelussa 1840-1950 välisenä aikana. Kielitieteellisen lähtökohtamme mukaan kieli on käytössä elävä ilmiö. Kieli uudistaa itseään ihmisten välisessä kommunikaatiossa ja käytänteissä osana kulttuuria ja yhteiskuntaa, eli se toimii myös maaseudun ja kaupungin suhteen välittäjänä ja ilmentäjänä.

Analyysissä keskeisenä tunnistettavana muodonmuutoksena seurasimme aiemmissa tutkimuksissa esitettyä havaintoa maaseutu-sanan yleisempien sanamuotoryhmien vaihtumista monikkomuotoisista ulkopaikallissijoista (maaseuduilla, maaseuduilta, maaseuduille) yksiköllisiin, ja sen jälkeen kieliopillisten sijojen, erityisesti genetiivin, nousua ulkopaikallissijamuotojen rinnalle. Alkuhypoteesina oli, että monikkomuotojen vaihtuminen yksikkömuotoihin liittyy kollektiivisen MAASEUTU-käsitteen vakiintumiseen maaseutu-sanan tärkeimmäksi viittauskohteeksi. Tutkimuksemme havainnot tukivat tätä hypoteesia.

Tutkimuksemme johtopäätöksenä esitämme, että suomen kielessä sanan maaseutu merkityksessä tapahtui 1850-1910 välisenä aikana semanttinen käänne, jonka myötä sanan merkitysrakenne muuttui. Muutos käynnistyi 1850-luvulla lähtien ja vauhtiin päästyään eteni suhteellisen nopeasti MAASEUTU-käsitteen muuttuessa yksiköllisen maaseudun tunnusmerkittömäksi merkitykseksi 1910 mennessä.

Muutoksen sisältöä voi luonnehtia seuraavasti: maaseutu sanalle alkaa vakiintua merkitys kategoriana, joka toisaalta irtautuu yksittäisistä paikallisuuksista ja rakentaa käsitystä yhtenäisestä, homogeenisesta maaseudusta. Tähän maaseutuun voidaan viitata yksinkertaisemmin ja kategorisemmin. Samalla maaseutu-sana abstrahoituu termiksi, jonka täsmällistä kuvaamista ei enää pidetä tarpeellisena. Tässä yhteydessä maaseutu-sana viittaa yleisesti kaikkiin alueisiin ja paikkoihin, jotka ovat kaupunkien ulkopuolella. Tämä irtoaminen yksittäisistä paikallisuuksista 
tekee maaseutu-sanasta alttiin monenlaisille merkityksenannoille ja siten hyvin käyttökelpoisen yhteiskunnallisissa ja poliittisissa keskusteluissa.

Seuraavaksi tarkastelemme yleisesti, mitkä tekijät vaikuttivat tuon käänteen taustalla tilanteessa, jossa Suomi haluttiin nähdä rakentumassa olevana kansallisvaltiona, jolla tulisi olla oma kielensä, valtiolliset instituutionsa ja kansallinen identiteettinsä.

Suomessa elettiin 1800-luvun puolivälissä merkittävien yhteiskunnallisten muutosten aikaa. Maa oli osa Venäjän keisarikuntaa, mutta samalla sen asema suurruhtinaskuntana oli mahdollistanut muutoksia, joiden tarkoituksena oli rakentaa omaa kansallista identiteettiä, ja lopulta muodostaa valtiollisia instituutioita, joiden avulla voitaisiin ottaa askelia kohti itsenäistä Suomea. Ruotsin kieli oli pitkään sekä eliitin että hallinnon kielenä senkin jälkeen, kun Suomi 1809 siirtyi osaksi Venäjää.

Aiheemme kannalta merkittävää on, että 180o-luvulla, erityisesti sen loppupuolella alkoi hiljalleen kehittyä myös poliittinen suomen kieli. Sanoja käännettiin ruotsista suomeksi, mutta samalla luotiin kokonaan uutta sanastoa, jolla oli tehtävä yhteiskunnallisen keskustelun ja politiikan kielessä. (Hyvärinen ym. 2003, 14; Saastamoinen 2003, Huumo, Laitinen \& Paloposki 2004.) Kansakunnan viralliseksi kieleksi suomi tuli vuonna 1863. Nähdäksemme maaseutu-sana on erityisen hyvä esimerkki kielen kietoutumisesta käyttöyhteyksissään aikakauden muutoksiin.

Nykysuomen etymologisessa sanakirjassa (Häkkinen 2013, 662) esitetään maaseutu sanan etymologisesta taustasta seuraavaa: "Kaupungin tai erityisesti pääkaupungin vastakohtaa merkitsevä maaseutu on oppitekoinen uudissana, jonka ensiesiintymä on Daniel Europaeuksen ruotsalais-suomalaisessa sanakirjassa vuonna 1853." Sanan oppitekoisuudella viitataan tässä käytäntöön, jossa oppineet kielen tuntijat, kuten tässä tapauksessa kansanrunouden kerääjä ja kielitieteilijä Europaeus (18201884), käänsivät ruotsinkielistä sanastoa suomeksi, koska sille oli eri aloilla suuri tarve. Samassa yhteydessä usein myös luotiin kieleen uudissanoja. Tuolloin ei luonnollisesti ollut mahdollisuutta kattavasti selvittää esimerkiksi juuri sanan maaseutu käyttöä suomenkielisessä sanomalehdistössä. Aineistossamme maaseutu ilmenee ensimmäisen kerran vuoden 1840 Mehiläinen-lehdessä. 
Suomalaiseen identiteettipolitiikkaan kuului oman kielen sekä laajasti tunnetun suomalaiseen kulttuurin ja taiteen vahvan roolin lisäksi monia käytännön muutoksia, joita pidetään nykyään keskeisinä itsenäisen valtion tunnusmerkkeinä. Suomi sai oman rahan vuonna 1860, armeijan 1878 ja hallinnon merkittävänä uudistuksena oli paikallisen kunnallishallinnon luominen 1865 alkaen. Vuonna 1812 perustetun Helsingin asema Suomen pääkaupunkina alkoi 180o-luvun puolivälin jälkeen vahvistua. Tämä oli pienessä maassa merkittävä asia, joka sai huomiota kaikkialla maassa. Samalla se ilmeisesti oli vahvistamassa juuri pääkaupungin ja maaseudun välistä jännitettä. Kansallisvaltion luomiseen liittyvät uudistukset muodostivat laajasti vaikuttavan kontekstin niille julkisille keskustelulle ja debateille, joihin maaseudun käsitteellinen muutos kiinteästi liittyi.

Suomi kehittyi hieman Eurooppaa viiveisemmin vaiheeseen, jossa teollistuminen ja yhteiskunnan modernisaatioksi kutsuttu kehitys alkoi vaikuttaa yhteiskunnan rakenteisiin. Muutos alkoi 180o-luvulla, mutta suuri taite agraarista teolliseen yhteiskuntaan tapahtui Suomessa kuitenkin vasta 1900-luvun puolella ollen kiihkeimmillään vasta toisen maailmansodan jälkeen. Tähän kytkeytyy oleellisesti Suomen kaupungistuminen ja kaupunkien kasvu (Haapala \& Lloyd 2018, 25). Tällainen rakennemuutos ei tapahdu ilman kitkaa ja jännitteitä, joissa myös yhteiskuntaluokkien suhteet politisoituivat.

Maaseudulla on ollut roolinsa näissä murroksissa. Niihin liittyvissä valtakamppailuissa maaseudun asemaan on kielen avulla pyritty vaikuttamaan monissa maissa. Maaseudun kielelliseen määrittelemiseen liittyviä kiistoja ja jännitteitä on tutkimuksissa kuvattu hegemonisena kamppailuna maaseudusta ${ }^{8}$. Käsitys modernissa yhteiskunnassa useilla tahoilla käytävistä johtajuus- ja valtakamppailuista ymmärretään yhteiskuntatieteissä pitkälti Antonio Gramschin (1977) ajatteluun perustuvaksi. Gramschin ajattelussa kielellä on keskeinen merkitys ja rooli (Ives 2004).

Hegemonisessa kamppailussa yhteiskuntaan vaikuttamaan pyrkivät toimijat ja toimijaryhmät yrittävät kaikin mahdollisin tavoin haastaa muita ideologioita ja erityisesti vaikuttaa omien ideologioidensa vahvistumiseen. Tähän liittyen Andy Pratt $(1996,76)$ esittää kiinnostavan havainnon: Gramsci (1973) nostaa 1920-luvulla Italian historialliseen tilanteen

8 Suomalaisista maaseutututkijoista erityisesti Olli Rosenqvist on (2004) korostanut maaseudun historiallista asemaa vahvojen yhteiskunnallisten merkityskamppailujen osana. 
analyysissä nationalismin ohella keskeiseksi poliittiseksi käsitteeksi juuri kysymyksen maaseudusta (ruralism). Voimme siis olettaa, että MAASEUTUA vastaavat käsitteet ovat muissakin kielissä olleet poliittisesti vaikutusvoimaisia.

Tulkintamme mukaan - Suomen kontekstissa - yhtenä tärkeänä osana yhteiskunnallista murrosta ja sen kamppailuja oli, että asemistaan kiinni pitävien agraarisuomen edustajien mielissä ja puheissa juuri abstraktiksi kategoriaksi muotoutunut MAASEUTU-käsite toimi erinomaisesti: se oli moniin eri suuntiin tärkeitä merkityksiä viestivä ja kietoi laajasti yhteen keskeisiä ajan ilmiöitä, intressejä ja ihmisiä. Maaseutu toimi vahvana poliittisena avainsanana yhteiskunnallisissa keskusteluissa ja poliittisessa toiminnassa. Analyysimme osoittaa, että prosessi, jonka myötä KÄSITE vakiintui julkiseen keskusteluun, oli varsin nopea. Näin sillä oli 1900-luvun alussa uutuuteensa liittyvää ajankohtaisuutta ja muutosvoimaa.

Tästä murrosten ajasta yksittäisenä, mutta vahvana kansallisena esimerkkinä voi esittää Maaseudun Tulevaisuus -lehden perustamisen 1916. Lehden syntyminen ja erityisesti sen kyky puhutella laajoja suomenkielisiä väestöryhmiä perustui oleellisesti siihen, että MAASEUTU-käsite oli tuolloin jo vakiintunut maaseutu-sanan keskeiseksi merkitykseksi. Lehti asemoi itsensä kaupunkien, ja erityisesti pääkaupungin, ulkopuolisen Suomen puolestapuhujaksi. Samalla se tunnustautui arvopohjaiseksi foorumiksi, jossa kaupungit asetettiin maaseudun poliittiseksi vastinpariksi (ks. Jumppanen 2021). Näin Maaseudun Tulevaisuus -lehti oli aktiivisesti synnyttämässä kuvaa maaseudun ja kaupungin välisestä suhteesta vastakkainasetteluna.

MAASEUTU-käsitteen myöhemmän käytön kannalta oleellinen havainto on, että edellä kuvaamamme muutoksen myötä syntynyt kollektiivisen MAASEUDUN käsite otettiin 1900-luvun alussa nopeassa tahdissa laajaan poliittiseen käyttöön. Poliittisen argumentaation myötä käsitteeseen latautui vahvasti yhteiskunnallisiin aatteisiin ja ideologioihin liittyviä merkityksiä. Tällä voidaan nähdä olevan suuri vaikutus käsitteen myöhempään käyttöön aina nykypäiviin asti. 


\section{Maaseutukäsitteen muutoksen jatkuvuudesta}

Suomessa maaseutu otettiin suhteellisen sujuvasti käyttöön myös akateemisena terminä. Maailmalta varsinainen maaseutututkimus rantautui Suomeen 1950-luvun lopulla. Tässä yhteydessä maaseutu sai yhteiskuntatieteissä (maatalouden rinnalla) jalansijaa niin, että 1970-luvulla kiinnostuttiin maaseudun kehityksen ja kehittämisen (suunnittelun) kysymyksistä. Vahvana vaikuttaneen maatalouspolitiikan oheen alkoi tuolloin tutkijoiden vaikutuksesta muotoutua uusi termi: maaseutupolitiikka. Sen läpimurto tapahtui 1980-luvun lopulla, ja ensimmäinen maaseutupoliittinen kokonaisohjelma esiteltiin Suomessa vuonna 1991.

Käsitteenä MAASEUTU on joustavasti taipunut monista suunnista tuleviin määrittelyihin. Tutkijoillakaan ei ole siitä yksiselitteistä määritelmää, joskin kaupungista eroavaksi entiteetiksi maaseutu yleisesti tunnistetaan. Tutkimuksessa vastakkainasettelusta on jo pitkää pyritty luopumaan: maaseutu-kaupunki asetelmaa lähestytään enemmän vastavuoroisena suhteena, jossa sekä kaupunkien että maaseutujen erilaistuneet paikallisuudet korostuvat (Shucksmith \& Brown 2016b; Rosenqvist 2020). Julkisessa keskustelussa maaseudun ja kaupungin vastakkainasettelu on kuitenkin edelleen elinvoimaista retoriikkaa.

Kielen käytön näkökulmasta arvioiden voitaneen sanoa, että eri ihmiset ja erilaisen identiteetin omaksuneet ryhmät luonnehtivat maaseutua nykyisin hyvinkin paljon toisistaan poikkeavilla tavoilla. Maaseutumielikuviin vaikuttavat ihmisten oma tausta, elämäntilanne ja kokemukset erilaisista maaseuduista. Samaan aikaan henkilökohtaiset mielikuvat ja tulkinnat maaseudusta elävät osana laajempaa yhteiskunnallista kehitystä ja sitä koskevia keskusteluja. Niihin myös median luomalla maaseutukuvastolla on vaikutusta. Kuitenkin se, että ihmisillä voi olla kokemuksia ja mielikuvia maaseudusta edellyttää maaseudun vakiintumista kategoriana, johon nuo kokemukset ja mielikuvat kohdistuvat. Juuri tällaisen kategorian vakiintumisen kielenkäyttöön 1850- ja 1910-lukujen välisenä aikana olemme edellä osoittaneet.

Julkista yhteiskunnallista keskustelua ei enää käydä pääasiassa sanomalehtien sivuilla, kuten vielä 100 vuotta sitten. Medioita on periaatteessa rajaton määrä. Sosiaalisen median foorumit mukaan lukien yhteiseen mediaympäristöön voi tuottaa sisältöä käytännössä kuka tahansa verkkoyhteyksiä käyttävä toimija. Nämä digitaaliset alustat tuottavat monimuotoista maaseutukuvastoa. Maaseutua koskeva keskustelu saa tässä 
ympäristössä kiihtyvästi uutta sisältöä. Samalla tämä kuvasto sekoittuu ihmisten henkilökohtaisiin, kokemuksellisiin maaseutumielikuviin. (Hyyryläinen \& Ryynänen 2018.)

Suomalaisten maaseutukuvia kartoitetaan nykyisin säännöllisesti kyselyillä. Uusimman, 2020 julkaistun maaseutubarometrin (Pyysiäinen \& Vihinen 2020) tulosten perusteella suomalaisten mielikuvat maaseudusta ovat lopulta melko perinteisiä, ja näkemykset maaseudusta ja kaupungista ovat pitkälti toistensa peilikuvia. Maaseutu yhdistetään erityisesti luontoon, ja maaseutumaisema on suomalaisille peltojen, metsien, kylien, kirkonkylien ja pienten taajamien sekä saariston ja tuntureiden näkymä.

Maaseutubarometria ei voida pitää kielitieteellisenä tutkimustuloksena siitä, mitä kyselyyn vastanneet ymmärtävät sanalla maaseutu. Mutta kyselyn tulosten voi tulkita kertovan siitä, että barometrikyselyn vastaajille maaseutu on ensisijaisesti tietynlaisen ympäristön yleistetty tyyppi ja maaseutu-sanan merkitys näin pääasiallisesti se kollektiivinen ja abstrakti käsite, johon viittaamaan sana havaintojemme mukaan viime vuosisadan vaihteessa erikoistui. Käsitteellisten erotteluiden merkitys näkyy mainitun kyselyn tuloksissa esimerkiksi siinä, miten asiantuntijoiden käsitykset eroavat keskimääräisestä tulkinnasta. Heille esimerkiksi myös laskettelukeskukset sopivat maaseudun määritelmään hyvin (49 \%), kun vastaavasti kansalaisista vain $12 \%$ näkee ne maaseutuna (emt.).

MAASEUTU-käsitettä voi nykyiseltä sisällöltään kuvata joustavaksi ja monimuotoiseksi. Sana on pääasiassa yksikkömuotoisessa käytössä. Monikkomuotoinen maaseudut ei ole yleisesti käytössä, vaikka se kielellisesti olisi luonnollisesti mahdollista. Maaseutu-sanaa ei edelleenkään käytetä kaupunki-sanan lailla kuvaamaan aktiivista toimijuutta, mutta kaupungit ovat kielenkäytössämme subjekteja, joilla on omaa politiikkaa ja tavoitteita. Maaseutu puolestaan on usein toimenpiteiden kohteen asemassa. Esimerkiksi maaseudun ympäristön ja elinkeinojen, erityisesti maatalouden tukemiseen käytettävät resurssit kohdistetaan Suomessa Manner-Suomen maaseudun kehittämisohjelmaksi nimetyn politiikkavälineen kautta.

Maaseutu-sanan käytössä on kiinnitetty huomiota (Hyyryläinen \& Ryynänen 2018, 33-34) siihen, että maaseutu-sana korvataan nykyisin jollain muulla sanalla, kuten kunta, alue, maakunta tai seutu. Esimerkiksi suomalaisten identiteettejä tarkastelevassa tuoreessa kyselytutkimuksessa (Pitkänen \& Westinen 2018) MAASEUTU-käsitettä ei käytetä 
lainkaan, vaan siihen viitataan muilla käsitteillä. Politiikka-asiakirjoissa on yleistä viitata maaseutuun käyttämättä tätä sanaa. Tämän voi tulkita valinnaksi, jonka taustalla on edellä kuvaamamme muutos: yleistettynä kategoriana MAASEUTU ei ole subjekti tai toimijaosapuoli. Sitä ei voi pitää kumppanina kuin metaforisesti, sillä sitä ei vastaa mikään hallinnollinen tai muu organisatorinen entiteetti. Kyseisten politiikkaohjelmien toimeenpanon osapuolina voidaan kuitenkin sujuvasti mainita kunta, täsmentämättä, onko kyse maaseutu- vai kaupunkikunnasta.

Vaikka kielessä tapahtuu jatkuvasti muutosta, on vaikeata nähdä, että suomen kielessä olisi tapahtumassa 1800-1900 lukujen taitteen kaltaista isoa muutosta MAASEUTU-käsitteen käyttötavoissa. Tutkijoiden tulkinnoissa maaseudun ja kaupungin vastakkainasettelusta ollaan pitkälti luopumassa, ja paikkojen erilaisuutta korostavat lähestymistavat ovat vahvistumassa. Tähän paikkojen erilaisuutta painottavaan suuntaukseen periaatteessa soveltuisi maaseutu-sanan monikkomuodon - maaseudut - käyttö sopivissa asiayhteyksissä. Tällaisia kielen muutoksia on kuitenkin mahdotonta ennakoida. Tulevaisuudessa maaseudun ja kaupungin suhteita välittävään kielenkäyttöön voi uutta merkityssisältöä odottaa generoituvan muutoksesta, jossa talous- ja tuotantojärjestelmämme sopeutuu kasvun kestävyysrajoihin.

\section{Lähteet}

Helsingin Uutiset 7.12.1863 https://digi.kansalliskirjasto.fi/sanomalehti/binding/447497 Hämeen Sanomat 1.10.1879 https://digi.kansalliskirjasto.fi/sanomalehti/binding/371043 Oulun Wiikko-Sanomia 6.10.1860 https://digi.kansalliskirjasto.fi/sanomalehti/ binding/412211

Otawa 19.1.1861 https://digi.kansalliskirjasto.fi/sanomalehti/binding/422578

Suometar 31.8.1855 https://digi.kansalliskirjasto.fi/sanomalehti/binding/424964

Uusi Suometar 16.5.1877 https://digi.kansalliskirjasto.fi/sanomalehti/binding/426602

Uusi Suometar no. 4 10.01.1879 https://digi.kansalliskirjasto.fi/sanomalehti/ binding $/ 427823$

Uusi Suometar 30.08.1880 https://digi.kansalliskirjasto.fi/sanomalehti/binding/426951 Vaasan Sanomat 4.8.1879 https://digi.kansalliskirjasto.fi/sanomalehti/binding/457242 Länsi-Savo, 19.6.2000. https://digi.kansalliskirjasto.fi/sanomalehti/binding/1021850 Länsi-Savo, 10.12.1917 https://digi.kansalliskirjasto.fi/sanomalehti/binding/1020693 Maamiehen ystävä 21.8.1847 https://digi.kansalliskirjasto.fi/sanomalehti/binding/421781 Mehiläinen 1/ 1840 https://digi.kansalliskirjasto.fi/aikakausi/binding/500568 


\section{Kirjallisuus}

Bloomfield, Leonard 1933. Language. Henry Holt.

Chambers, J. K. \& Peter Trudgill 1998. Dialectology (2nd ed.). Cambridge University Press.

Eckert, Penelope 2016. Variation, meaning and social change. Teoksessa Coupland, Nikolas (Ed.), Sociolinguistics: Theoretical Debates (68-85). Cambridge: Cambridge University Press. https://doi.org/10.1017/СВ09781107449787.004

Engman, Max 2018. Kielikysymys. Svenska litteratursällskapet i Finland, SLF.

Europæus, David Emanuel Daniel 1853. Svenskt-finskt handlexikon $=$ Ruotsalaissuomalainen sanakirja. Helsingfors: [Finska litteratur-sällkapet]. Print.

Gkartzios, Menelaos 2018. Mobilities beyond Counterurbanization: Questiones of Context. 2018. Teoksessa Kordel, Stefan, Tobias Weidinger \& Igor Jelen (eds.). Prosesses of Immigration in Rural Europe. The Status Quo, Implications and Development Strategies. Cambridge Sholars Publishing. 2-24.

Gramsci, Antonio 1973. Selections from Prison Notebooks (edited and translated by Hoare, Q. and Nowell-Smith, G.). Lawrence and Wishart. London.

Gramsci, Antonio 1977. Quaderni del Carcere. Volume primo, quaderni 1-5. Edizione critica dell Istituto Gramsci. A cura di Valentino Gerratana. Torino: Einaudi.

Haapala, Pertti \& Christopher Lloyd 2018. Johdanto: Rakennehistoria ja historian rakenteet. Teoksessa Haapala, Pentti (toim.) 2018. Suomen rakennehistoria. Näkökulmia muutokseen ja jatkuvuuteen (1400-2000). Vastapaino. 6-30.

Hakulinen, Auli, \& Fred Karlsson 1979. Nykysuomen lauseoppia. Suomalaisen Kirjallisuuden Seura.

Huumo, Katja 2006. "Perkeleen kieli”: suomen kieli ja poliittisesti korrekti tiede 1800-luvulla. Suomen tiedeseura.

Huumo, Katja, Lea Laitinen \& Outi Paloposki (toim.) 2004. Yhteistä kieltä tekemässä: Näkökulmia suomen kirjakielen kehitykseen 1800-luvulla. Suomalaisen Kirjallisuuden Seura, Helsinki.

Hyyryläinen, Torsti \& Toni Ryynänen 2018. Maaseutukuvat ja -mielikuvat maaseudun kehittämisessä. Maaseudun uusi aika 26/2-3. 24-38. Saatavilla: http://www. mua-lehti.fi/wp-content/uploads/2018/10/hyyrylainen-ja-ryynanen.pdf

Hyyryläinen, Torsti \& Elina Vallas 2016. Maaseudun ja kaupungin muuttuva suhde sanomalehdissä 1800-ja 1900-lukujen vaihteessa - miten maaseuduista tuli maaseutu? Esitelmä maaseutututkijatapaamisessa 25.8.2016. Saatavilla: https:// tuhat.helsinki.fi/ws/portalfiles/portal/67906615/Hyyrylainen Vallas maaseutu vs maaseudut 160825.pdf

Hyvärinen, Matti, Jussi Kurunmäki, Kari Palonen, Tuija Pulkkinen \& Henrik Stenius (toim.) 2003. Käsitteet liikkeessä: Suomen poliittisen kulttuurin käsitehistoria. Vastapaino. Tampere.

Häkkinen, Kaisa 2013. Nykysuomen etymologinen sanakirja. Sanoma Pro. Helsinki. Ives, Peter 2004. Language and Hegemony in Gramsci. Pluto Press.

Jumppanen, Aapo 2021. Maaseutu on kaupungin äiti - Maaseudun ja kaupungin vastakkainasettelu Maaseudun Tulevaisuuden sivuilla 1916-1918. Teoksessa Maaseutututkimus, vol. 29 Teema. 66-98. https://doi.org/10.51807/ maaseutututkimus. 112888

Karlsson, Fred 2008. Yleinen kielitiede. (Uud. laitos). Gaudeamus Helsinki University Press. 
Kemmer Suzanne \& Michael Barlow 2000. Introduction: A Usage-Based Conception of Language. Teoksessa Barlow, Michael, \& Kemmer, Suzanne (2000). Usage-based models of language. CSLI Publications, Center for the Study of Language and Information. vii-xxviii.

Laitinen, Lea 2008. Maamme - meidän maa. Maamme-laulun versioita: suomennoksia ja muunnelmia. Virittäjä, 112(1), 84. Noudettu osoitteesta https://journal.fi/virittaja/ article/view/40642

Laitinen, Lea \& Taru Nordlund 2013. Language from below? Indexing Identities in the Writings of Common People in 19th-Century Finland. Teoksessa Anna Kuismin \& M. J. Driscoll (eds.), White Field, Black Seeds. Nordic Literacy Practices in the Long Nineteenth Century, Studia Fennica Litteraria. Suomalaisen Kirjallisuuden Seura. Saatavilla: https://oa.finlit.fi/site/books/10.21435/sflit.7/

Lauerma, Petri 2013. Finnish revivalist movements and the development of literary Finnish especially in the first half of the 19th century. Teoksessa Kuismin, Anna \& Matthew Driscoll (toim.). White field, black seeds: Nordic Literary Practises in the Long Nineteenth-Century, Studia Fennica Litteraria 7. Suomalaisen Kirjallisuuden Seura, 158-168.

Lyons, John 1977. Semantics. Cambridge University Press.

Marjanen, Jani, Ville Vaara, Antti Kanner, Hege Roivainen, Eetu Mäkelä, Leo Lahti \& Mikko Tolonen 2019. A National Public Sphere? Analysing the Language, Location and Form of Newspapers in Finland, 1771-1917. Journal of European Periodical Studies, 4(1), 54-77. https://doi.org/10.21825/jeps.v4i1.10483

Nordlund, Taru \& Ritva Pallaskallio 2017. Competing norms and standards: Methodological triangulation in the study of language planning in nineteenth-century Finland.

Teoksessa Säily, Tanja, Arja Nurmi, Minna Palander-Collin \& Anita Auer (toim.) 2017. Exploring Future Paths in Historical Sociolinguistics. John Benjamins. 131-156.

OED Online. "rural, adj. and n." OED Online. Oxford University Press, December 2020.

Phillipson, Robert 1992. Linguistic Imperialism. Oxford University press.

Piispanen, Sirkku \& Torsti Hyyryläinen 2015. Kaupungin herrat ja salomaiden ymmärtämättömät asukkaat. Maaseutu ja kaupunki Mikkelin paikallislehtien keskusteluissa 1861-1910. Helsingin yliopisto, Ruralia-instituutti. Raportteja 157. https://helda.helsinki.fi/handle/10138/229430

Pitkänen, Kaarina 2008. Suomi kasvitieteen kieleksi: Elias Lönnrot termistön kehittäjänä. Suomalaisen Kirjallisuuden Seura.

Pitkänen, Ville \& Jussi Westinen 2018. Sittenkin suomalaisia? Tutkimus suomalaisten identiteeteistä. Raportti 1. e2 ja Suomen Kulttuurirahasto. Saatavissa: https://www. e2.fi/hankkeet-ja-julkaisut/julkaisut/sittenkin-samanlaisia-tutkimus-suomalaistenidentiteeteista.html

Pratt, Andy C. 1996. Discourses of Rurality: Loose Talk or Social Struggle? Journal of Rural Studies. Vol 12, 69-78.

Pyysiäinen, Jarkko \& Hilkka Vihinen 2020. Maaseutubarometri 2020. Tutkimusraportti osa 1. https://www.maaseutupolitiikka.fi/uploads/MANE-raportit/Maaseutubarometri2020-osa-1.pdf

Reuter, Mikael 2005. Landsorten och landsbygden. Reuters ruta 9/3 2008. Kotimaisten kielten keskus. https://www.sprakinstitutet.fi/sv/publikationer/sprakspalter/reuters rutor 1986 2013/2005/landsorten_och_landsbygden 
Rosenqvist, Olli 2004. Maaseudun asemoituminen myöhäismodernissa yhteiskunnassa. Acta Wasaensia. No 129. Aluetiede 9. Universitas Wasaensis.

Rosenqvist, Olli 2020. Deconstruction and hermeneutical space as keys to understanding the rural. Journal of Rural Studies. 132-142.

Saastamoinen, Kari 2003. Johdatus poliittisiin käsitteisiin uuden ajan alun Ruotsissa. Teoksessa Hyvärinen, Matti, Jussi Kurunmäki, Kari Palonen, Tuija Pulkkinen \& Henrik Stenius (toim.) 2003. Käsitteet liikkeessä: Suomen poliittisen kulttuurin käsitehistoria. Vastapaino. Tampere. 19-61.

de Saussure, Ferdinand 1912 [1983]. Course in General Linguistics. Duckworth. Lontoo. Shucksmith, Mark \& David L. Brown 2016a. Framing Rural Studies in the Global North. Teoksessa Shucksmith, Mark \& David L. Brown (eds.). Routledge International Handbook of Rural Studies. Routledge. 1-26.

Shucksmith, Mark \& David L. Brown 2016b. Rural Studies: The Challenges Ahead. Teoksessa Shucksmith, Mart. \& David L. Brown (eds.). Routledge International Handbook of Rural Studies. Routledge. 663-675.

Tuggy, David 1993. Ambiguity, Polysemy and Vagueness. Cognitive Linguistics. 4. 273290. https://doi.org/10.1515/cogl.1993.4.3.273.

VISK = Auli Hakulinen, Maria Vilkuna, Riitta Korhonen, Vesa Koivisto, Tarja Riitta Heinonen ja Irja Alho 2004: Iso suomen kielioppi. Helsinki: Suomalaisen Kirjallisuuden Seura. Verkkoversio, viitattu 1.11.2008. Saatavissa: http://scripta.kotus.fi/visk URN:ISBN:978-952-5446-35-7

Woods, Michael 2005. Rural Geography. London Sage.

Woods, Michael 2011. Rural. Routledge. London. 